\title{
EL ESCULTOR ENRIQUE GUERRA
}

\section{Por José Rojas Garcidueñas}

Arte: difícil, duro, ingrato, es el de la escultura.

Difícil el aprendizaje y el dominio de su técnica; más difícil el logro de la expresión. Como en todas las artes plásticas, lo fundamental reside en lo que el artista pueda y sepa ver. El ojo humano $-\mathrm{y}$ en eso tenían razón los pintores impresionistas- lo que percibe son colores; en rigor no vemos otra cosa que manchas de color, que la experiencia y la educación de los sentidos instantáneamente transforman en apreciación de objetos y de distancias: yo miro una mancha blanca rectangular, miro una delgada y alargada mancha en dos o tres tonos de amarillos y ocres y una manchita negra; yo sé que lo blanco es el papel, los amarillos, ocres y negros es un lápiz, eso lo sé pero mi ojo sólo ve colores. Eso es lo regular y ordinario, pero tal parece como si los ojos de ciertas y muy contadas personas funcionaran de modo extraordinario. Así el grabador, que procede como si no mirara ningún color, como si mirara sólo blanco y negro (que en pintura no son colores), es decir, sólo luz y sombra. También, de otro modo, el escultor, que parece no ver sino volúmenes. ¿Deformación óptica? No; disposición y conformación anímica. Pero iqué difícil un arte que arranca del vencimiento y transformación de una función fisiológica dada!

Arte duro, que requiere mucho esfuerzo psíquico y físico. Al escultor hay que situarlo en uno de los renglones que señalan mayores molestias y desgaste físico: horas y más horas de pie, con las manos húmedas manejando, modelando el barro o el yeso, que agrietan la piel; días y más días tallando las piedras, intuyendo (eso no se puede saber) el levísimo cambio de posición de la mano izquierda que fija la dirección del filo del cincel y la fuerza y delicadeza precisas con que la mano derecha golpeará con el mazo, ya que de la combinación de posición y golpe depende el corte que se haga a la piedra ... y eso repetido miles y miles de veces.

Es cierto que todo arte requiere considerable esfuerzo físico. El público generalmente no se da cuenta de eso, y más de una vez ha pensado que convendría hablar de ello, tanto para disipar arraigadas supervivencias romanticoides: "el arte, cosa etérea que surge del invisible toque de la musa", como porque una sana divulgación de cultura ar- 
tística requiere la concomitante divulgación de nociones elementales de las técnicas, el "oficio", de cada género de arte.

Además de duro y difícil, la escultura es un arte muchas veces in. grato. De ningún modo sería cosa de sostener ahora (en esta segunda mitad del siglo $x x$, saturada de alegatos y polémicas sobre la naturaleza y relaciones sociales del arte) que el artista debe trabajar por sólo la "gloria" y la "fama", actitudes también florecidas hace siglo y medio. Desde otro lado, tampoco es Iugar aquí de adentrarse en esos puntos de la teoría del arte, tales como si la creación artística es necesidad de expresión personal o si el arte no debe ser más que un artesanado, sujeto a las condiciones económicas privativas, o si es una manifestación de la clase en el poder, etc., etc. Todo eso es muy interesante pero también es muy complejo $y$, por lo mismo, no debe de ser tratado sino en las condiciones adecuadas y nunca superficialmente o como cuestión marginal de otro problema del arte, porque esos defectuosos y deficientes tratamientos conducen siempre a errores y malos entendimientos, como es fácilmente demostrable con abundancia de pruebas. Pero, cualquiera que sea la posición que se adopte frente al fenómeno de la creación artística, es innegable que el artista desea y generalmente necesita el ser conocido y, de ser posible, aplaudido y elogiado por sus contemporáneos. El contacto con el público varía mucho en las diferentes ramas de las bellas artes: en algunas es inmediato, como en la ejecución musical, en el ballet y en el teatro; en. otras es más diferido y lento, como en la literatura y en las artes plásticas. Sin embargo, cuando el lector tiene en sus manos una novela sabe quién la escribió, cuando mira un cuadro o un grabado puede ver la firma, o bien el catálogo de la exposición o del museo le informan sucintamente del autor. Me refiero al arte contemporáneo; bien sabemos todos que el problema es distinto tratándose del arte anterior al Renacimiento.

Mas el caso del escultor presenta otras modalidades: no cuando presenta o toma parte en una exposición, sino cuando su obra, como es frecuente, queda como ornamentación de un edificio o como monumento religioso, cívico, sepulcral o casos similares; entonces la escultura queda allí, con más o menos frecuencia es mirada fugaz y descuidadamente por pocas o por muchas personas, y podríamos preguntar ¿cuántas de ellas se preocupan o interesan por inquirir, siquiera, el nombre del artista? $\mathrm{Y}$ a veces es peor todavia: la escultura suele quedar inadvertida, ya sea por el sitio recóndito de su colocación o bien, como ocurre hoy en día en muchísimos casos, precisamente al contra- 
rio, porque la ubicación de tal escultura: es algún punto tan concurrido, en estas nuestras enormes ciudades, que junto a la obra de arte pasan diạriamente miles de individuos viéndola sin mirarla, tanto por el apresuramiento del vivir citadino cuanto porque el hábito y la rutina disuelven el interés y hasta la simple curiosidad. $Y$ así re sulta la paradoja de que la obra escultónica mientras más permanente es, tanto más parece provocar el olvido y la ignorancia de quien la hizo.

Se dirá que lo importante no es, en modo alguno, saber nombres y fechas de autores, sino que lo importante es lo que la obra de arte, en sí y por sí misma, expresa y comunica a quien la contempla. Así es, en efecto. Nada sabemos de quién labró el ángel sonriente de la catedral de Reims y menos aún de quién labró la Coatlicué, y el valor artístico de esas esculturas en nada se amengua por el hecho fortuito de ignorar sus respectivos autores. Mas la cuestión de nuestra escultura moderna es otra: por una parte, es indudable que, en nues: tro mundo de hoy, aquí y ahora (como gustan decir los historicistas) sí tiene importancia el reconocimiento o el desconocimiento de un artista como tal. Tiene importancia para él mismo y, en consecuencia, para su labor, para su obra.

Esa consecuencia se produce en varios modos, de los cuales los más considerables son, probablemente, dos: el psicológico y el económico: En lo psicalógico, que yo prefiero llamar lo subjetivo y anímico, el reconocimiento público del artista como autor de tales y cuales obras opera en él como estímulo muy poderoso (salvo casos de misantropia más o menos desarrollada). No es vanagloria censurable, porque si la obra hecha es meritoria, la gloria o fama no es vana sino razonable y justa. No es, tampoco, la ya mencionada posición romántica de que el artista trabaja y crea sólo alentado por el anhelo de gloria. Lo que sí es innegable es que, artista o no artista, todos esperamos y deseamos el reconocimiento de nuestro esfuerzo y lo meritorio de nuestra labor; el que ésta tenga o no mérito efectivo es otra cuestión, ahora me refiero al aspecto que he llamado subjetivo o animico. En resumen, todos buscamos tener nuestro "lugar bajo el sol" y ese deseo, como impulsar de la acción y del trabajo opera en el investigador de laboratorio, en el profesor, en el técnico, en el profesionista, en el hombre de empresa, etc., como en el artista.

El otro aspecto del reconocimiento de la obra de arte es el económico. El artista que profesionalmente lo es, y precisamente para serlo, tiene que vivir del producto de su actividad artística, es decir, de su obra. (Señạlar excepciọnes, aquí como en cualquier otro campo, nada 
demuestra.) Además, en muchos casos puede verse que el artista innato, o sea el individuo con claras facultades artisticas, si elude el profesio nalismo de su arte, por ejemplo porque su fortuna personal le evite la necesidad de trabajar, frecuentemente decae o desemboca en el dilettantismo.

Sería superfluo reincidir en el trillado tema de las dificultades que tiene, comúnmente, el artista para vivir de su arte, pero si cabe senalar que, en el caso particular del escultor, concurren mayores dificultades que en otras ramas del arte: por el costo intrínseco de la obra escultórica, por el largo tiempo que requiere su ejecución $y$, sobre todo, por el reducidísimo mercado que tiene hoy la escultura. Todo eso concurre desfavorablemente al conocimiento de la escultura y al reconocimiento valorativo de las obras escultóricas y de sus autores por lo que podemos llamar el público. Es, pues, un problema de carácter social.

En algunos países, y así ocurre muy especialmente en México, el desconocimiento de la escultura atañe, por desgracia, a todos sus diversos niveles, desde la investigación documental y erudita hasta la divulgación y vulgarización. Dije que eso acontece en algunos países, porque no es fenómeno general: por ejemplo, en Italia, su enorme acervo escultórico, con ser tan rico, está bien conocido: la bibliografia de estudios y monografías es copiosa; la historia de su arte, en tratados y manuales, consagra siempre gran espacio a la escultura; los monumentos públicos, religiosos o civiles, suelen ofrecer al espectador datos sobre su autor, fecha y otras circunstancias; las guías, también en sus diversos niveles, desde las eruditas hasta las elementales turísticas también proporcionan información más o menos amplia y profunda, según los casos. Pero en México nada de eso tenemos: nuestra historia del arte está aún insuficientemente explorada. Avanzar en ese terreno es una de las tareas a cargo del Instituto de Investigaciones Estéticas y de su desempeño informan los estudios publicados tanto en obras especiales como los recopilados en estos Anales. Nuestros museos son pobres en esculturas, excepto en lo precortesiano en que, al contrario, casi sólo hay esculturas; nuestros monumentos públicos que tienen obras escultóricas carecen de datos sobre sus autores $y$, en contraste, son ridículamente pródigos, sobre todo los de épocas recientes, en mencionar largas listas de funcionarios políticos y administrativos cuyo sólo mérito parece ser el que cobraban sueldos del erario nacional en el tiempo en que el monumento aquel se erigió finalmente, los órganos de divulgación artística: libros de arte no para especialis- 
tas, guías, etc., son aún escasos en número y en información, aunque muestran adelanto en los últímos años.

En conclusión: todo lo que sea conocer y dar a conocer las obras y sus autores, en el campo de la escultura mexicana, en diversos niveles y para diferentes públicos, creo que es labor cada día más necesaria. Un paso en ese camino son las notas que siguen, sobre el casi ignorado escultor don Enrique Guerra, para las cuales he aprovechado las notas biográficas y la lista de sus obras que generosamente me han sido facilitadas por el arquitecto don Jorge Guerra, hijo del escultor mencionado. Las otras fuentes utilizadas van mencionadas como es costumbre.

Nació Enrique Guerra en Jalapa, Veracruz, el 8 de noviembre de 1871; allí pasó su niñez, en el antiguo barrio de Techacapa, alternando sus tareas escolares con ocupaciones y trabajos diversos para ayudar a su familia, que se encontraba en situación económica muy precaria. así fue desde monaguillo en San José de Techacapa hasta aprendiz de talabartero, que era el oficio de su padre, en el cual pronto empezó a destacarse; muy joven ascendió a ser jefe de un taller de talabartería y, aplicando sus propias innatas habilidades, no tardó en llegar a ser un "repujador y ornamentista" de fama en la región.

Ese incipiente renombre le valió la ayuda del gobernador del Estado, don Teodoro A. Dehesa, quien le otorgó una beca para que estudiara en la Escuela Preparatoria del Estado. Allí empezó Enrique Guerra a demostrar sus dotes para el dibujo de tal modo que su profesor, el pintor Catucci, lo señaló como candidato a una beca para ir a México y estudiar en la Academia de San Carlos. ${ }^{1}$

Nuevamente el gobernador Dehesa le otorgó la beca correspondiente y Guerra vino a México, inscribiéndose en la Academia el año de 1893, probablemente ya iniciados los cursos, pues sus seis años de estudios parece que comenzaron a contar, regularmente, descle el de 1894. Entre sus maestros él solía recordar a don José María Velasco, en pintu.

1 En esa época el nombre oficial de la institución era "Escuela Nacional de Bellas Artes". Las sucesivas denominaciones que ha tenido son: "Academia Real de San Carlos de Nueva España", "Academia Nacional de San Carlos de México", "Academia Imperial de San Carlos de México". "Escuela Nacional de Bellas Artes" y "Escuela Nacional de Artes Plásticas", que es el nombre actual. Pero solenos llamarla, todavia, Academia de San Carlos, por costumbre y para evitar con. fusiones con la Escuela de Artes Plásticas, de la Secretaria de Educación Pública. 
ra, y al escultor Miguel Noreña, pero naturalmente tuvo otros diversos profesores, algunos de merecido renombre como Rebull.

De su etapa de aprendizaje académico quedan dos obras, a las que lucgo më referiré. En la exposición de la escuela, del año 1898, figuraron dos dibujos, sin nombre, de Enrique Guerra, entre los alumnos de la clase de "Dibujo nocturno [es decir, que el curso se daba por la noche] tomado del natural, bajo la dirección del señor profesor $D$. Santiago Rebull", y no menos de ocho piezas de escultura, de la "clase de escultura y ornato, bajo la dirección del señor profesor D. Enrique Alciati", que el catálogo correspondiente menciona así: "Núm. 20: Busto de niño, estudio del natural. E. Guerra.-Num. 21: Bajorrelieve, Academia, E. Guerra.-Núm. 22: Busto del Sr. D. Francisco Gasca, E. Guerra.-Núm. 23: Agar e Ismael, estudio de composición, E. Guerra.Núm. 24: Psiquis y el amor, estudio de composición, E. Guerra.-Núm. 25: Aníbal moribundo, idem. E. Guerra.-Núm. 26: La Aparición de Cristo a la Magdalena, idem, E. Guerra.-Núm. 27: Busto del Sr. Director de la Escuela D. Román S. de Lascuráin, E. Guerra". ${ }^{2}$

Es evidente que Guerra fue un alumno laborioso y aprovechado; su vocación era segura y en esos años juveniles ya la seguía con firmeza, cómo lo hará después toda su vida.

Del final de sus estudios en México quedan dos bajorrelieves, en yeso: "Asesinato de César" y "Coroliano", que le fueron premiados en 1899 y 1900. Se conservan en la Academia de San Carlos.

Terminados sus estudios, Guerra vuelve a su tierra natal pero no permanece allí mucho tiempo. Sus méritos estaban demostrados y con justicia obtiene, por tercera vez, la ayuda del que fue su eficaz y loable protector, el señor Dehesa, quien le asignó una pensión para que perfeccionara, en Europa, los conocimientos en la profesión que habia elegido.

Guerra se translada y radica en París al comenzar este siglo. Alli se inscribe en la Escuela de Bellas Artes, pero también asiste a la Academia Julien, entonces considerada como más renovadora y más propicia al desenvolvimiento personal de los artistas, mientras que la escuela tradicional era eso: muy tradicional. De sus profesores, encuentro los nombres de Frémiet y Verlet en las notas que me proporcionó don

2 Catálogos de las exposiciones de la antigua Academia de San Carlos de México (1850-1898). Edición de Manuel Romero de Terreros. Serie, Estudios y Fuentes del Arte en México, vol. Xıv. Instituto de Investigaciones Estéticas. UNAM, México, 1963, pp. 608-609. 
Jorge Guerra, y el de Couiller en un importante artículo de González Peña, que mencionaré adelante.

Durante sus años de vida en París, Guerra trató mucho a Rubén Dario y entre ambos se formó una amistad cordial y afectuosa de la que Guerra guardó hondo recuerdo. Dario era cuatro años mayor que Guerra, de hecho pertenecian a la misma generación, que fue la generación del "modernismo" literario hispanoamericano, cuyos epígonos nacen entre 1867 y 1875.3

La señora viuda de Guerra me refirió que cuando su marido estaba esculpiendo "Voluptuosidad", lo visitaba mucho Rubén Darío y, al verlo trabajar, un día le dijo: "El barro es la vida, el yeso es la muerte, el mármol es la resurección." El escultor guardó fielmente en su memoria ese pensamiento del poeta y más tarde relató esa anécdota a su esposa.

También en París, como en México, Enrique Guerra estudió y trabajó seriamente y con fruto. Desde luego, y además del esfuerzo que siempre implica la adaptación a un medio social desconocido y extranjero, hubo de hacer otro, mucho más considerable e importante, mayor y más profundo: el choque y la progresiva asimilación de un lenguaje artístico nuevo. En efecto, la formación artística que Guerra llevaba era casi estrictamente clásica, mejor dicho académica. Porque la enseñanza en San Carlos de México, todavía en los últimos años del siglo pasado, estaba orientada por la dirección academista que venía desde la época de Vilar y siguió a través de sus discípulos como Noreña, por más que ese academismo ya se habfa matizado de romanticismo, en el último cuarto del siglo, como lo demuestran numerosos ejemplos: baste citar el "Tormento de Cuauhtémoc", relieve de Gabriel Guerra (acaso lejanamente emparentado con el sujeto de estas notas), de 1885 ca., y esculturas de Jesús F. Contreras como el monumento a La Paz, en Guanajuato, 1898; sin referirme a otras como "Desespoir" y "Malgré tout", que ya ofrecen evidentes influencias postrománticas, pero que no hacen aquí al caso pues es seguro que Enrique Guerra no las conoció en la época a que me refiero, pues ambas esculturas datan de los comienzos de este siglo, cuando ya Guerra no estaba estudiando en la capital y posiblemente ya hasta había salido del país rumbo a Europa. En cuanto a la técnica, al "métier", no cabe duda que Guerra

3 Rubén Darío (1867-1916). Ricardo Jaimes Freyre (1868-1933). Amado Nervo (1870-1919). Guillermo Valencia (1873-1943). Leopoldo Lugones (1874-1938). Julio Herrera Reissig (1875-1910). José Santos Chocano (1875-1934). Enrique Gómez Carrillo (1875-1927). 
llegó a París con un oficio bien aprendido, bueno y eficaz, tanto para modelar como para esculpir.

Enrique Guerra debe de haberse percatado, con cierta sorpresa que los escultores, en París, los más de ellos marchaban por rumbos muy distintos a los viejos caminos por donde aún iban caminando los profesores de la Academia mexicana. En el París de los comienzos del siglo xx el academismo estricto había quedado muy atrás y el romanticismo (nunca muy fructifero en la escultura) también había sido rebasado. Para decirlo en dos palabras, puesto que no se trata de anarlizar aquí el arte extranjero, en esos años de la "la belle époque", el pasado inmediato en escultura era Carpeaux y el presente era Rodin.

Eso mismo, aunque de modo mucho más explícito y matizado, dice una de las mejores historias francesas del arte, en párrafo que es pertinente transcribir aquí porque esas líneas y otras complementarias que se verán más adelante, creo que ayudan mucho a entender la trayectoria artística de Enrique Guerra. El párrafo aludido dice así:

"Si nous prenons l'art plastique en France après 1850, il est certain que, dans son ensemble, il reste encore, et pour une assez longue période de temps, delibérément classique, $A$ peine quelques manifestations isolées... viendront-elles y jeter une note exceptionnelle de romantisme attardé. Mais le réalisme véritable qui était au fond de la doctrine d'apparence classique de Rude pénètre peu à peu partout et éclate, avec le goùt intense de la vie et du mouvement, dans l'oeuvre entière de Carpeaux ... Le naturalisme, qui s'affirmait en peinteure dès 1848, ne pénètre que tardivement la sculpture, après 1870 , et avec un succès moins général et moins caractérisé. Pui si rien ne rappelle en sculpture l'évolution des peintres vers les clartés éclatants et subtiles de l'impressionisme, un esprit neuf, servi par des qualités techniques nouvelles crée, avec Rodin, un art ou se mélangent étrangement la fougue véhément des romantiques et certaines aspirations, certains partis pris classiques, la science véridique des réalistes et une recherche de plus en plus passionée de l'expression vivante et frémissante jusqu'à l'extrême, par le mouvement et le modelé."

Con esas distintas y nuevas corrientes artísticas, vale decir con esos diferentes lenguajes - cada arte es un lenguaje y cada estilo una variante, puesto que cada uno de ellos es un medio distinto de expresión- fue con los que hubo de enfrentarse y de luchar el escultor mexicano. Lo hizo y con aprovechamiento.

4 Histoire de l'Art. Publiée sous la direction de André Michel. Tome vin, 2e partie. Librairic Armand Colin, Paris, 1926, pp. 510.511. 
Obras suyas, de aquellos años parisienses, son: "Sulamitha dans le rêve", yeso, que obtuvo una Mención Especial en el Concurso de la Academia Julien, en 1904; "Prometeo", yeso, presentado en 1905 en concurso análogo al citado, en el que obtuvo un primer premio; "Voluptuosidad", mármol, de 1905; "Crisálida", mármol, que en 1905 obtuvo primer premio en el Salón de los Artistas Franceses, hoy conservado en la colección "Enrique Guerra" que guardan sus familiares; "Caín y Abel", yeso, de 1906, que obtuvo Mención en el concurso anual de la Academia Julien; de la misma época son otros dos yesos: "La caza del oso" y "Mendigo", este último obtuvo Mención Especial en el Gran Salón de Escultores de 1906, en París. Finalmente mencionaré "Epave" y "Amor y Psiquis", que deben proceder de 1905 ó 1906.

Terminados sus estudios en París hizo un viaje por Italia, ${ }^{\circ}$ en el que sin duda se saturaría en la contemplación de las infinitas esculturas, desde las etruscas hasta las entonces contemporáneas, en los museos y monumentos de las ciudades italianas.

A fines de 1906 vuelve a México. Ya no es un desconocido: tiene cierto renombre, trae consigo sus lauros justamente conquistados y una parte de la obra que realizó en París, la que presenta al público poco después de su llegada. La Revista Moderna, publicación de letras y arte de gran prestigio por las firmas que en ella colaboran, saluda el regreso de Enrique Guerra y reproduce, en fotograbados, no menos de quince esculturas suyas y un retrato de su autor.

Bien vale la pena copiar, aqui, textualmente, los “pies" de esos grabados, pues son parte de lo que podríamos denominar catálogo de la obra de Guerra; en el orden en que aparecen, son éstos: "Sulamitha dans la [sic] rêve. Salón de 1904. París. [Es detalle de la obra total].Prometeo. Boceto.-Cain y Abel. 1" Mención Academia Julián. París.Estudio [desnudo masculino, figura completa, de pie].-Estudio [desnudo femenino, figura completa de pie].-Voluptuosidad.-Mendiante. Salón de 1906.-Crisalyde. Salón de 1905. París.-Estudio [desnudo masculino, de pie].-Gigolette.-Sulamitha dans le rêve [La figura completa].-Estudio [desnudo femenino, sedente, apoyado en el brazo izquierdo].-La caza del oso. París.-Epave.-Estudio [desnudo masculino, de pie, en las manos una cadena rota]. ${ }^{8}$

El año de 1908 (o acaso un poco antes, en 1907), modela un yeso

5 Carlos González Peña: "El escultor Enrique Guerra", en El Universal, jueves 4 de marzo de 1943 , p. 3.

Bevista Moderna de México, diciembre de 1906, pp. 195, 199, 202, 205, 207, 211 , 213 y 216. 
policromado: "Thais", que artísticamente corresponde a aquella etapa parisina, que termina con esta última obra.

Otra etapa, la tercera, comienza inmediatamente, va a ser la de obras mayores esculpidas o modeladas, para el Estado y a veces por pedidos particulares. Esta será otra fase en la que, por la naturaleza de las obras, la magnitud de ellas, su destino, etc., el escultor cambia un tanto su dirección y diríase que olvida (aunque luego la recordará) la orientación de su etapa de París.

Para fortuna del artista, poco tiempo déspués de su regreso a la patria recibe un importante encargo oficial: cuatro estatuas y una águila de mármol, que habrían de ser colocadas en el remate de la fachada principal de la Secretaria de Relaciones Exteriores, cuya reforma se había encomendado al arquitecto Nicolás Mariscal, en esos días de 1907, de modo que el edificio completo, decorado y amueblado pudiese estar listo para las recepciones y festejos del centenario de la Independencia, en septiembre de 1910. No hay constancias de quién fue el autor de la idea o temas de las esculturas (o si lo fue el mismo escultor), ni quién lo relacionó al artista recién llegado con el citado arquitecto o con su pariente don Ignacio Mariscal, Secretario de Relaciones Exteriores, pues solamente uno $u$ otro pudo tener autoridad para contratar con el escultor una obra que iba a costar considerable suma al presupuesto nacional.

Con fecha 13 de noviembre de 1907 se firmó un convenio cuyos puntos importantes (los otros se refieren al procedimiento para los pagos y otros detalles burocráticos), dicen así:

Contrato entre el Sr. Lic. D. José Algara, Subsecretario de Relaciones Exteriores y el Sr: Escultor D. Enrique Guerra para la ejecución en mármol de los modelos de las esculturas de la fachada proyectada por el Sr. $\mathrm{Arq}^{9}$ D. Nicolás Mariscal.

19 El Sr. Guerra se compromete a labrar en mármol modelos de las cuatro estatuas del Atico y del escudo del remate central habiendo desarrollado previamente al tamaño de ejecución dichó modelos.

2: Las estatuas tendrán dos metros, setenta centímetros de altura y se ejecutarán lo mismo que el escudo en mármol blanco de Carrara del más apropiado para la intemperie.

$3^{\mathrm{a}}$ El precio de las obras es en total de diez y seis mil cuatrocientos ochenta $y$ dos pesos de los que tres mil quinientos corresponden a cada estatua y los dos mil cuatrocientos ochenta y dos restantes al escudo.

$4^{a}$ El plazo para la terminación de la obra será de diez y ocho meses contados desde la fecha... 


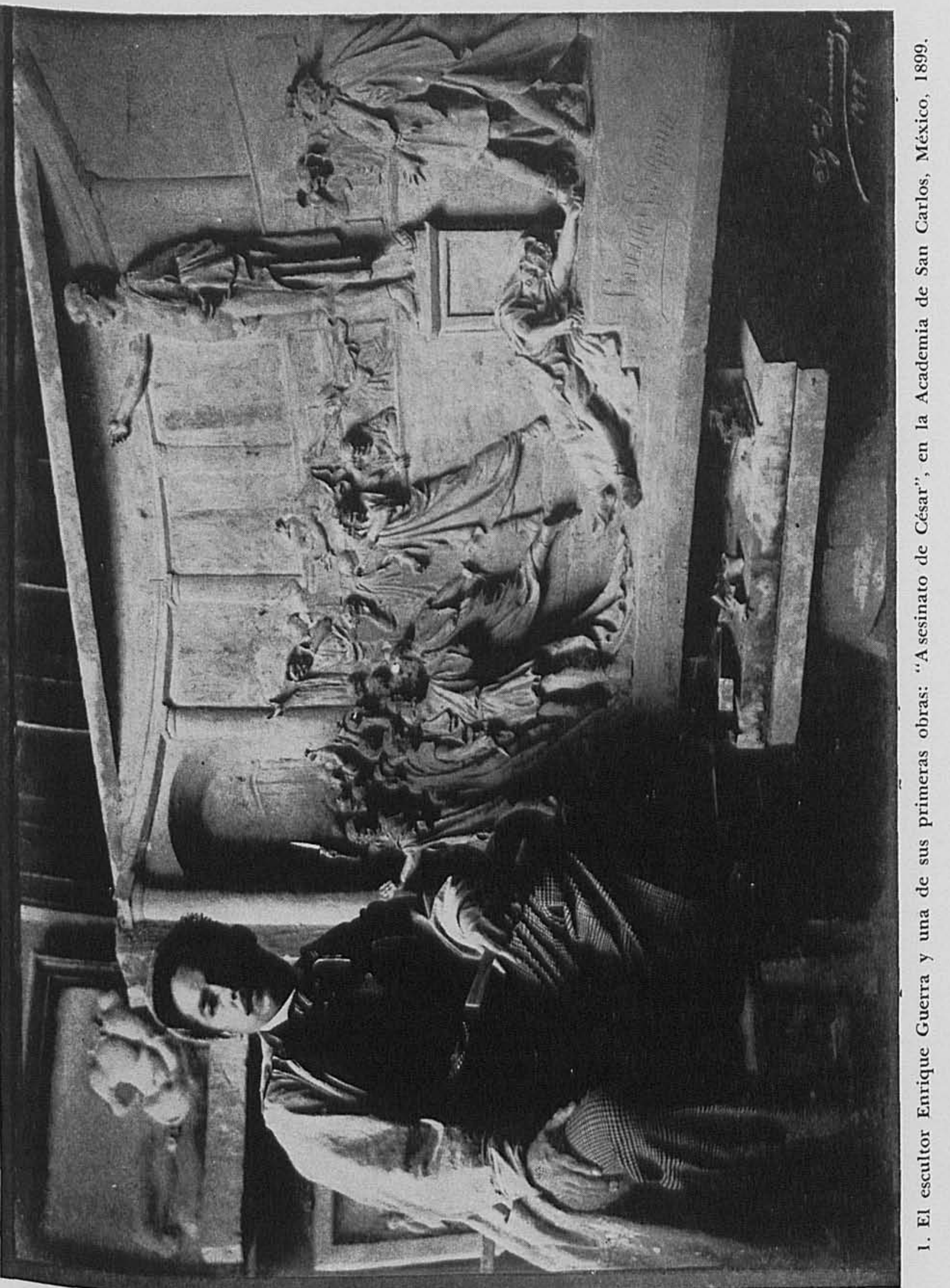


DOI: http://dx.doi.org/10.22201/iie.18703062e.1965.34.809

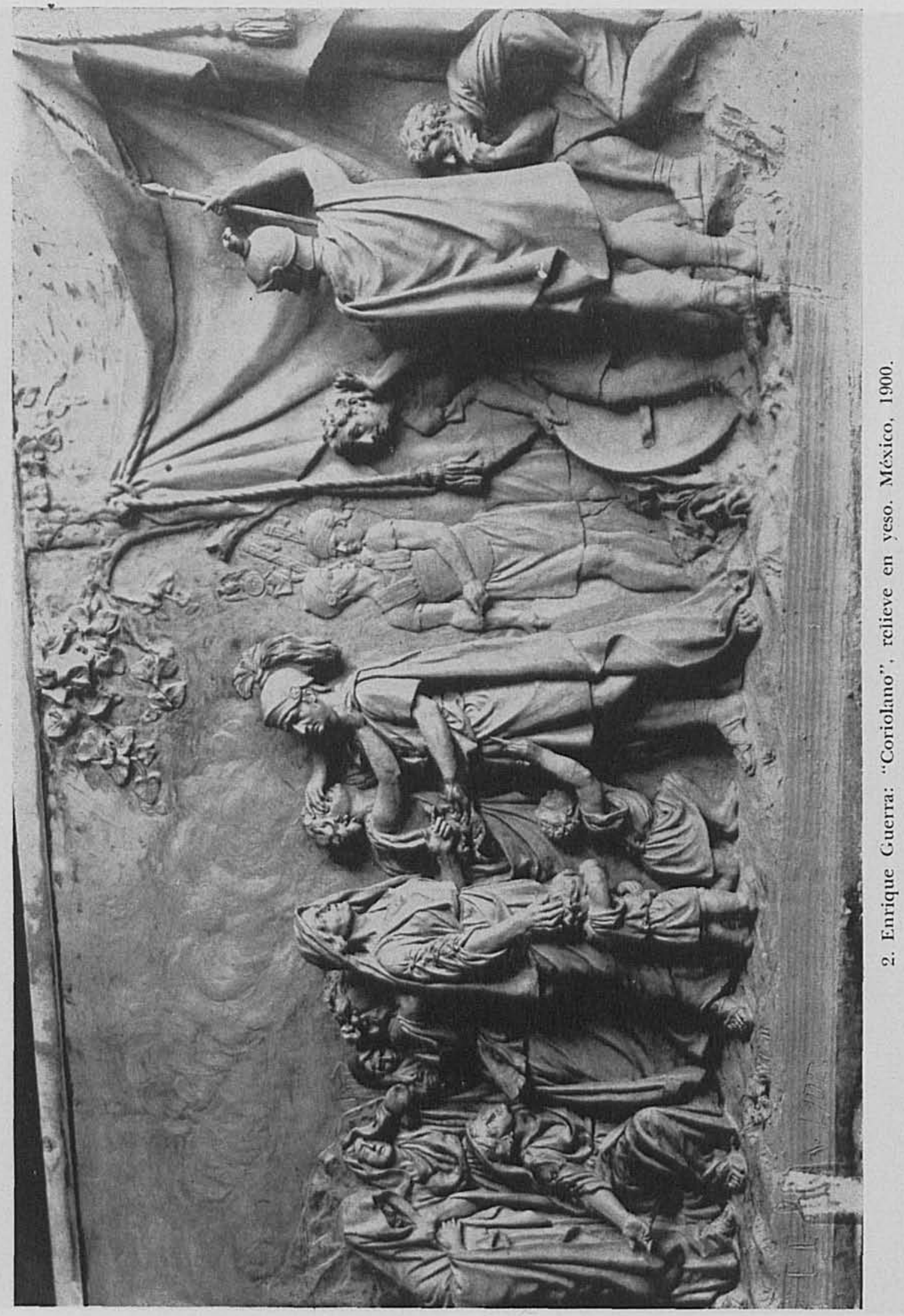




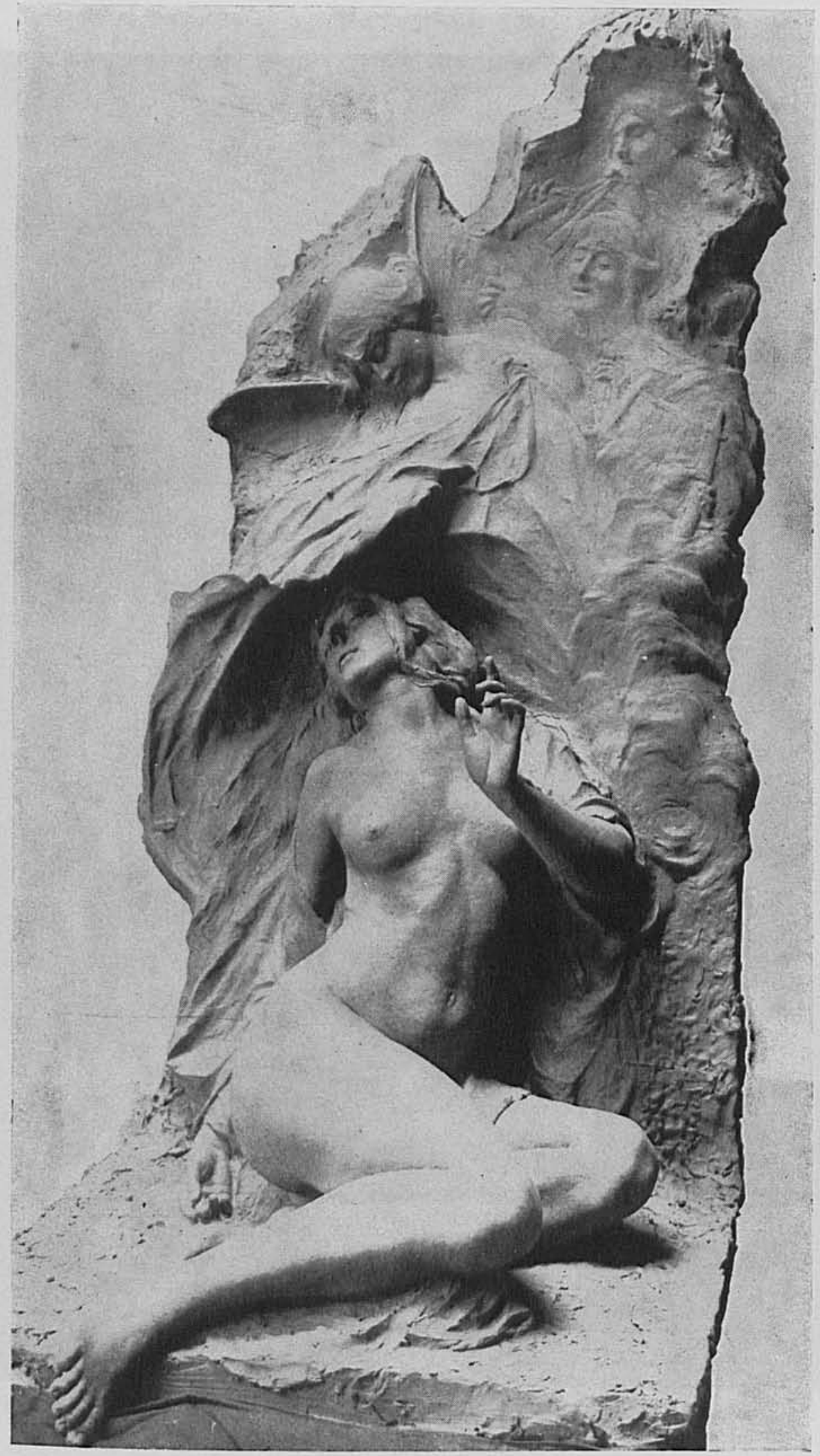

3. Enrique Guerra: "El sueño de Sulamita”. Paris, 1904. Yeso, colección E. Guerra. 


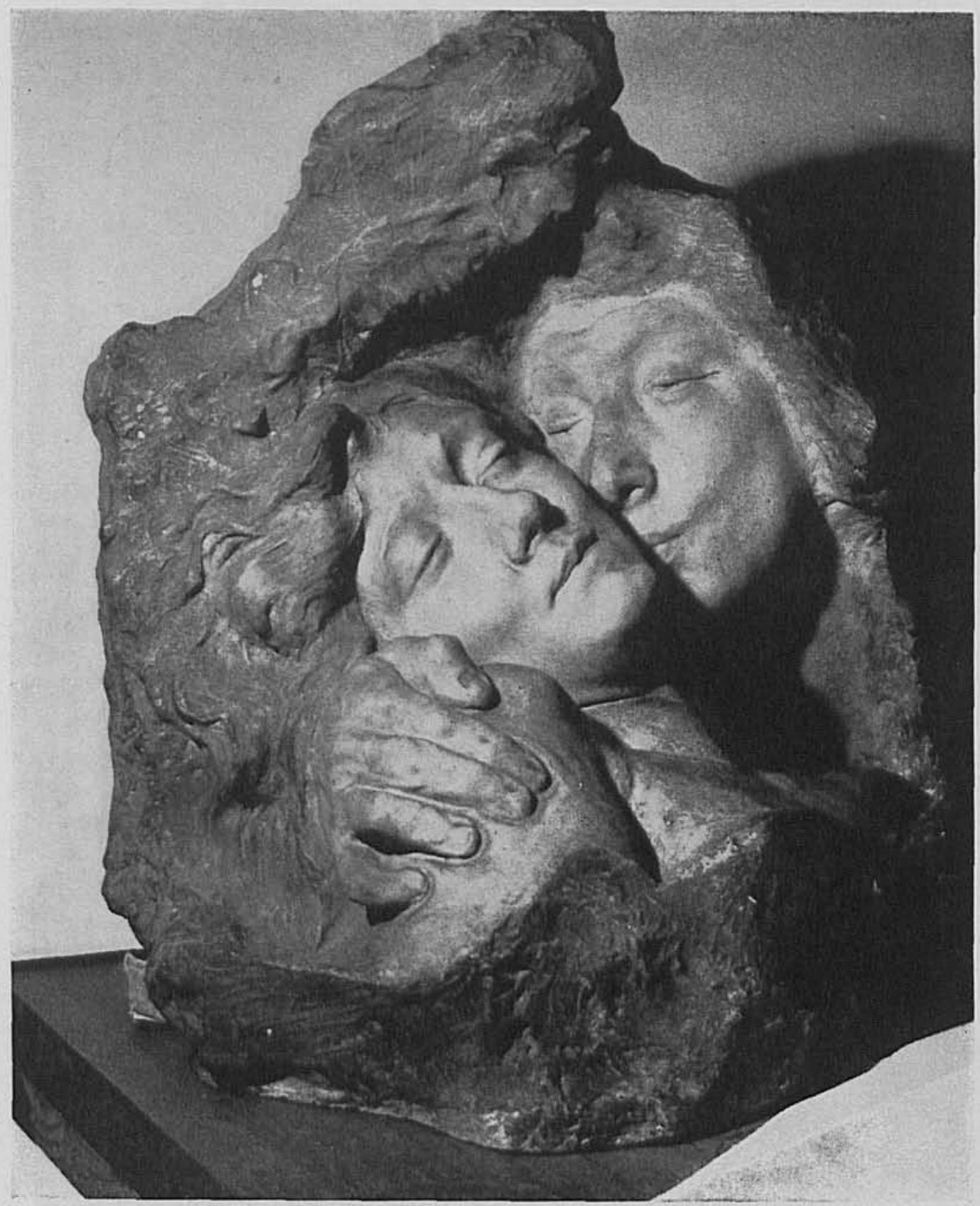

4. Enrique Guerra: "El beso". Paris, 1905. Yeso, colección E. Guerra. 


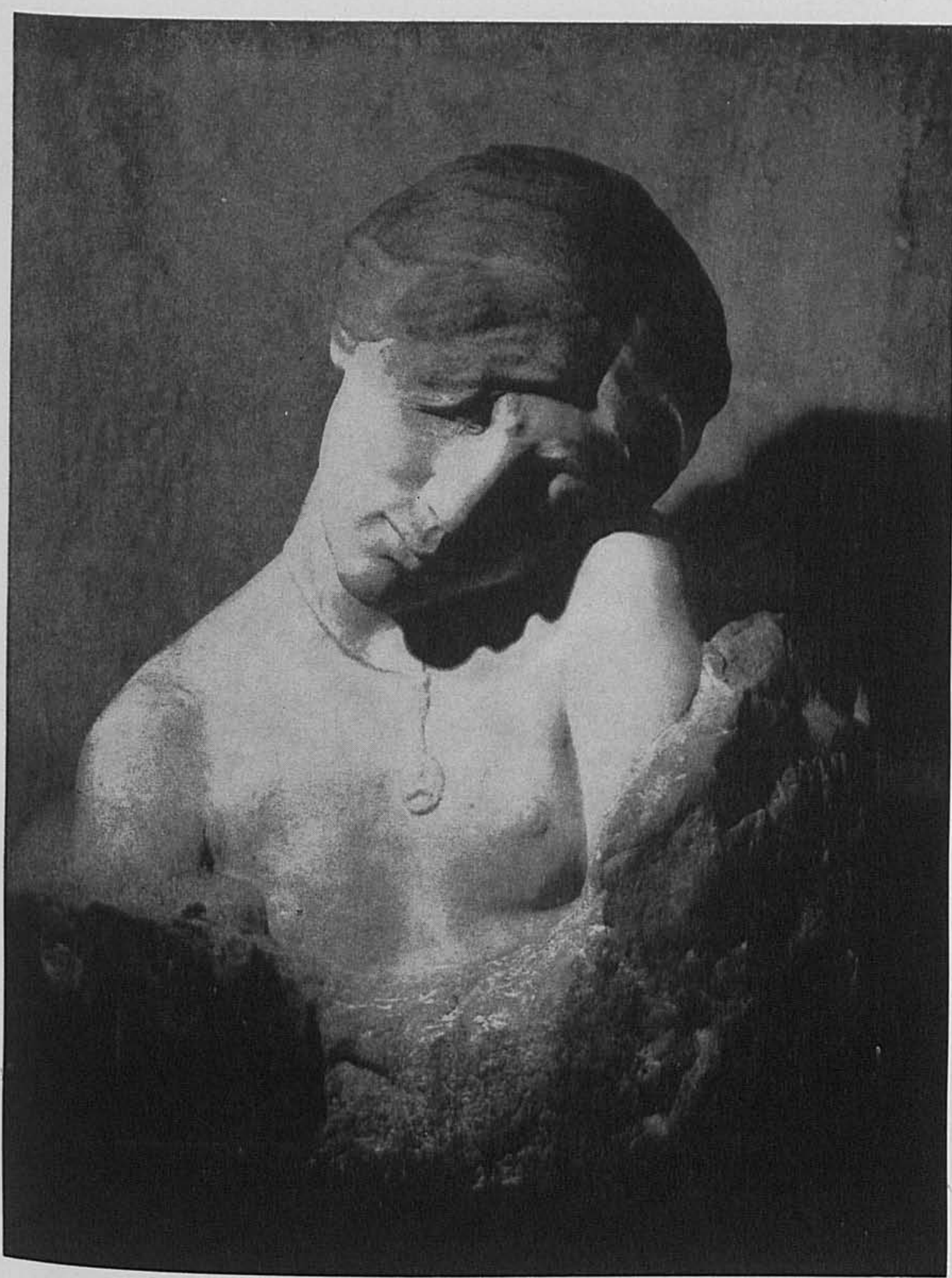

5. Enrique Guerra: “Crisálida”. París, 1905. Mármol, colección E. Guerra. 
DOI: http://dx.doi.org/10.22201/iie.18703062e.1965.34.809

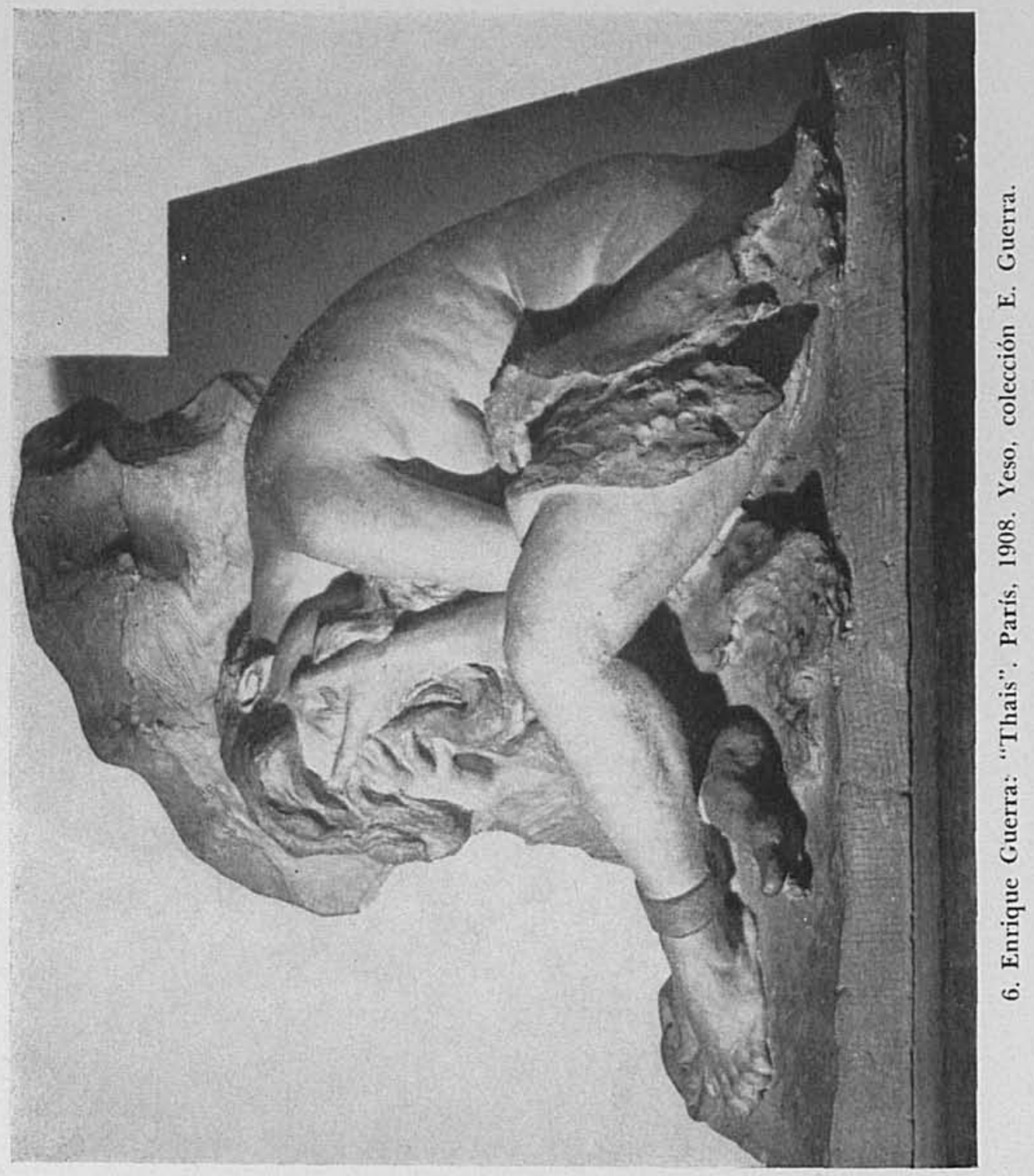




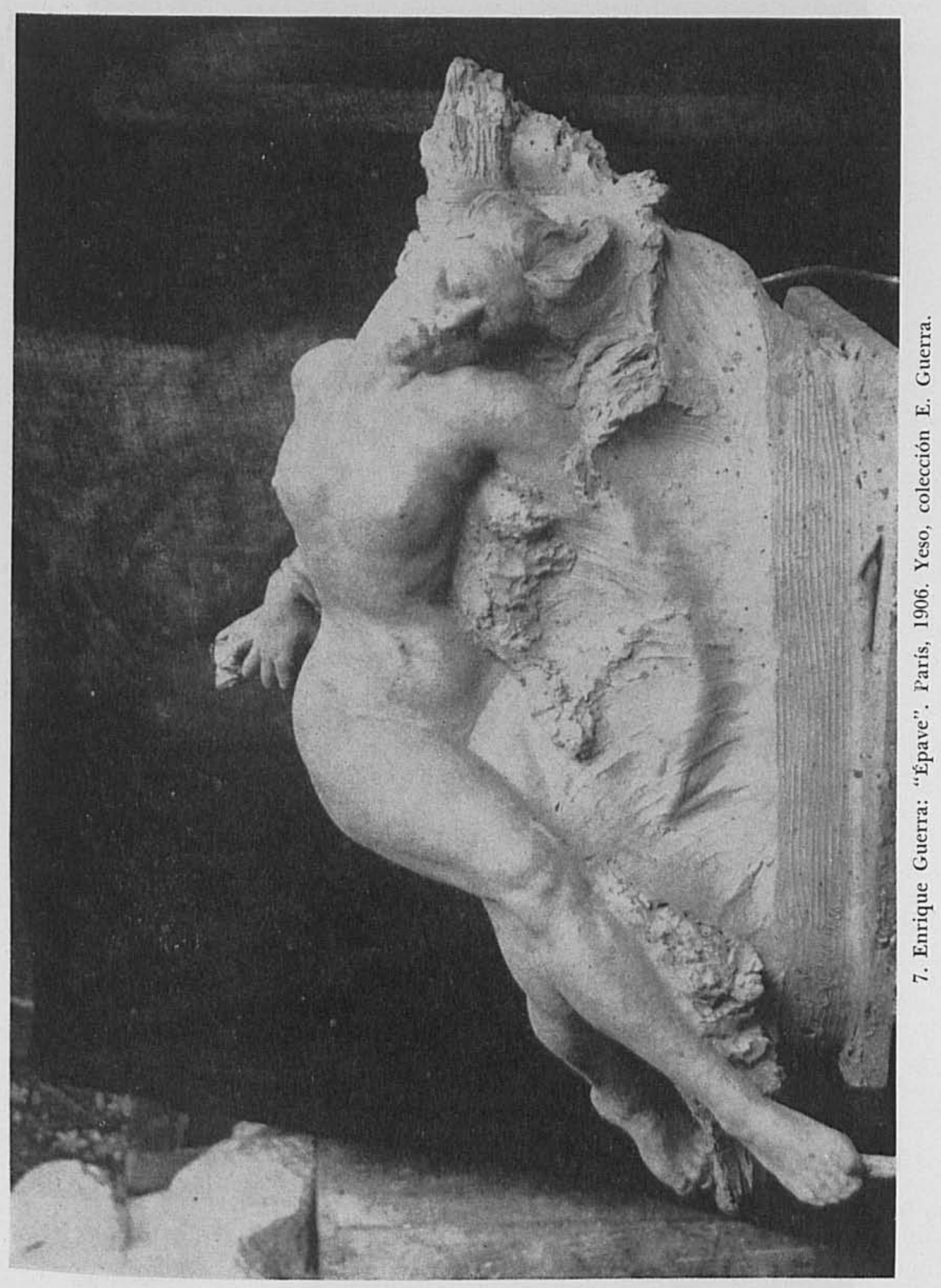


DOI: http://dx.doi.org/10.22201/iie.18703062e.1965.34.809

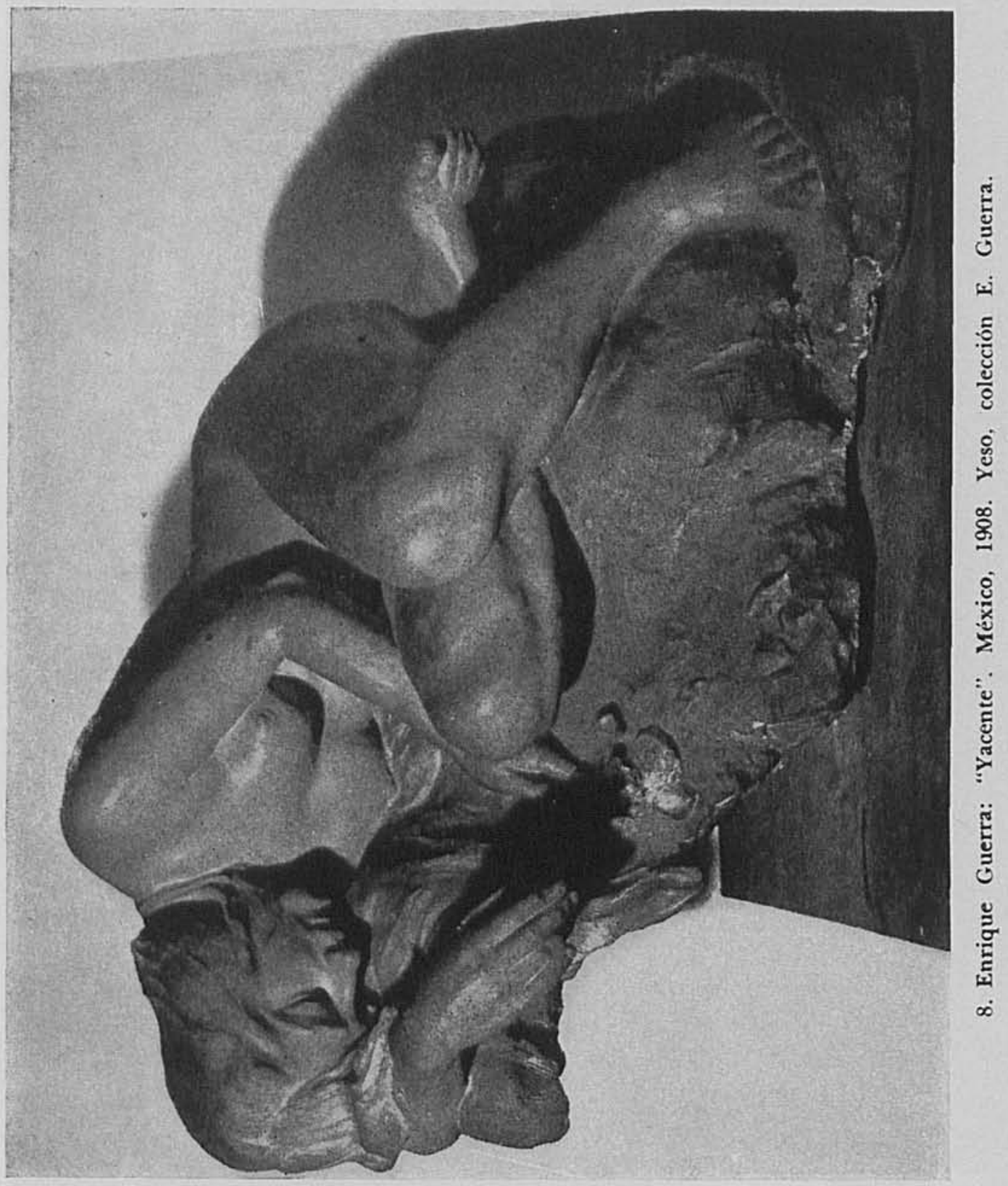




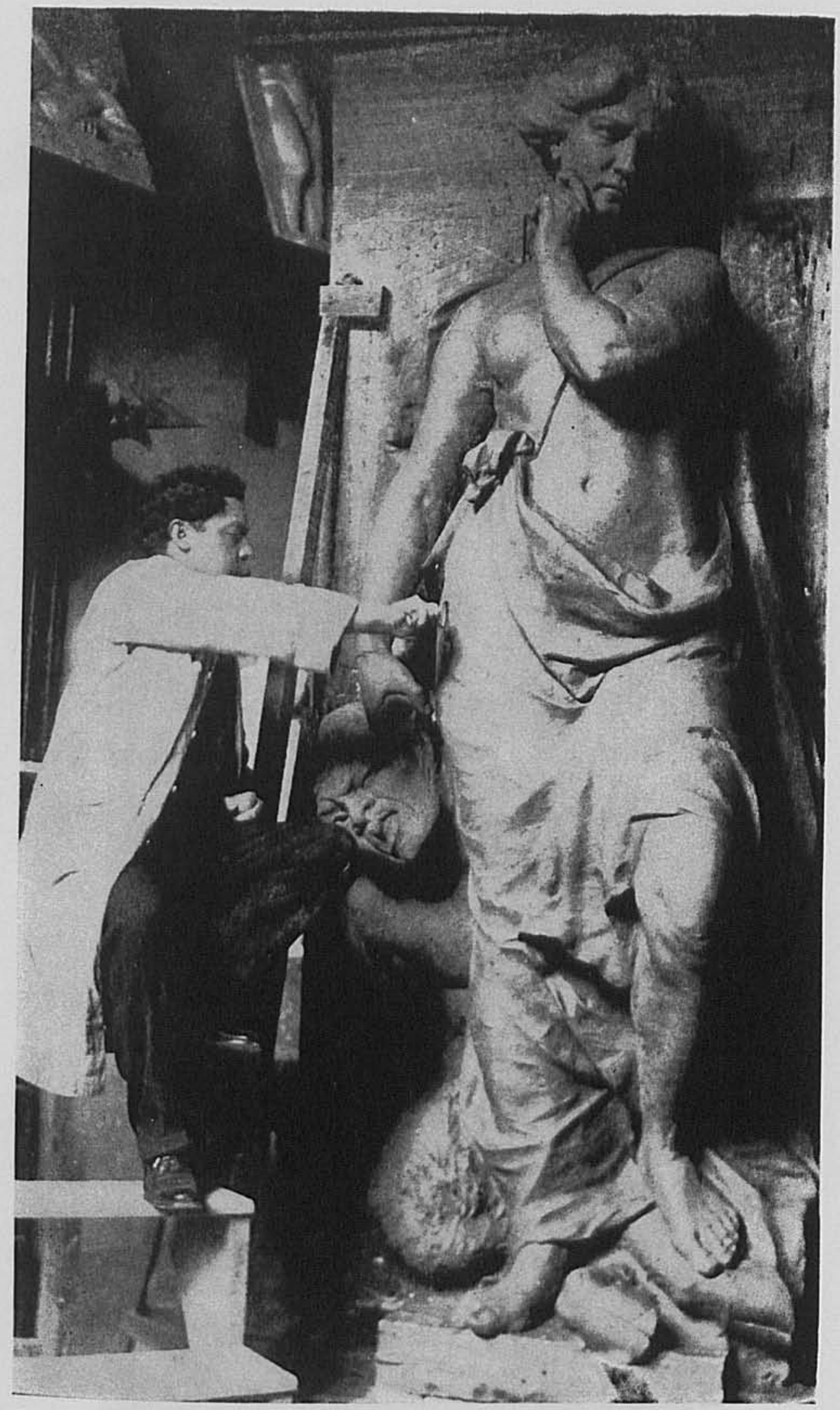

9. El escultor Enrique Guerra modelando en yeso el original de "La Prudencia". México, 1908. 


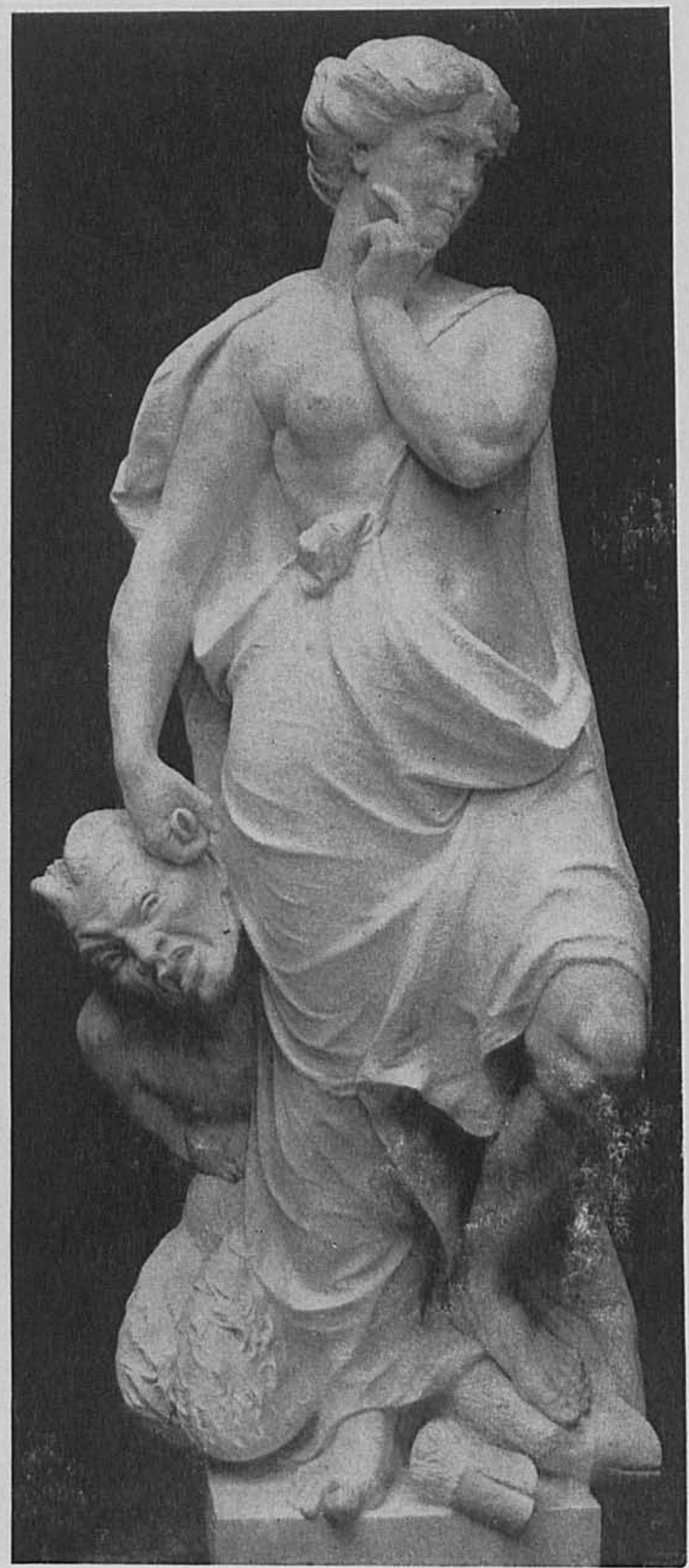

10. Enrique Guerra: "La Prudencia”. Mármol, 1909. En Jalapa, Veracruz. 
DOI: http://dx.doi.org/10.22201/iie.18703062e.1965.34.809

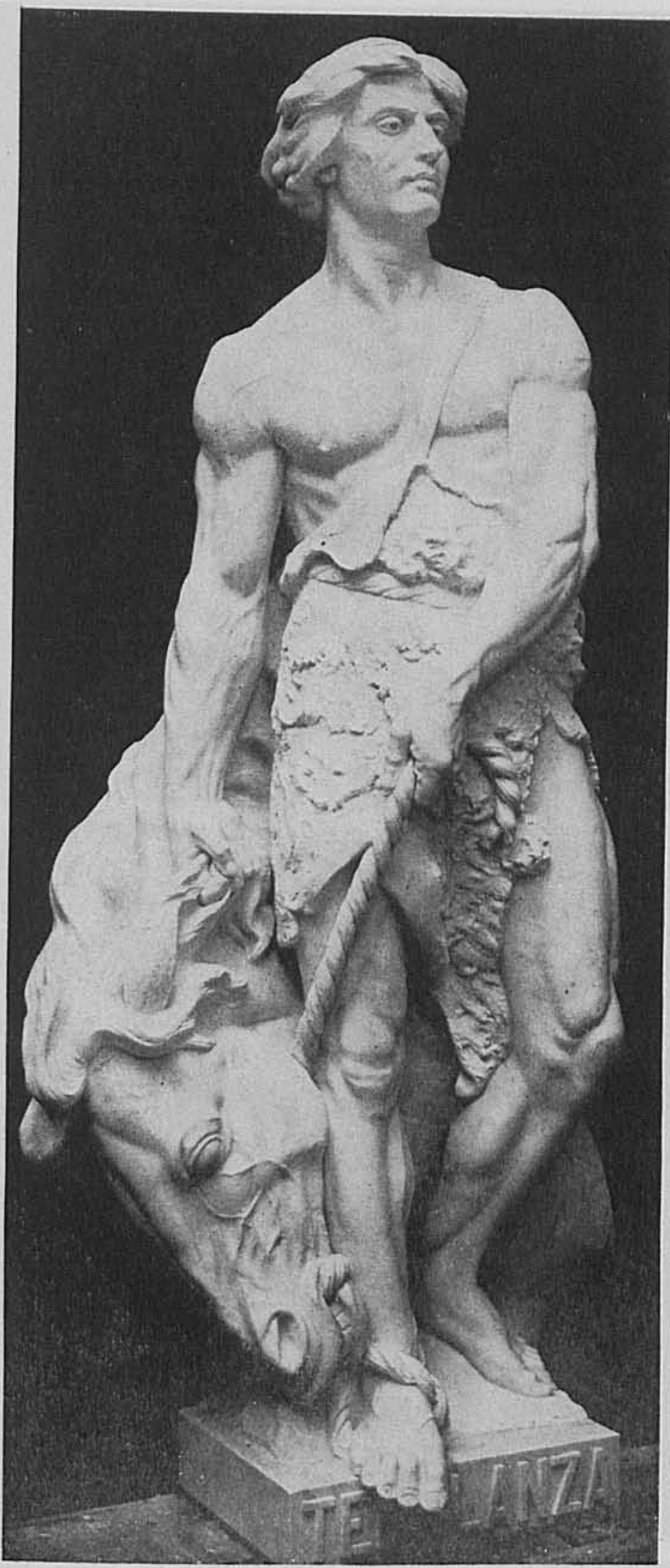

11. Enrique Guerra: "La Tempianza". Mármol, 1909. En el Bosque de Chapultepec, México, D. F. 


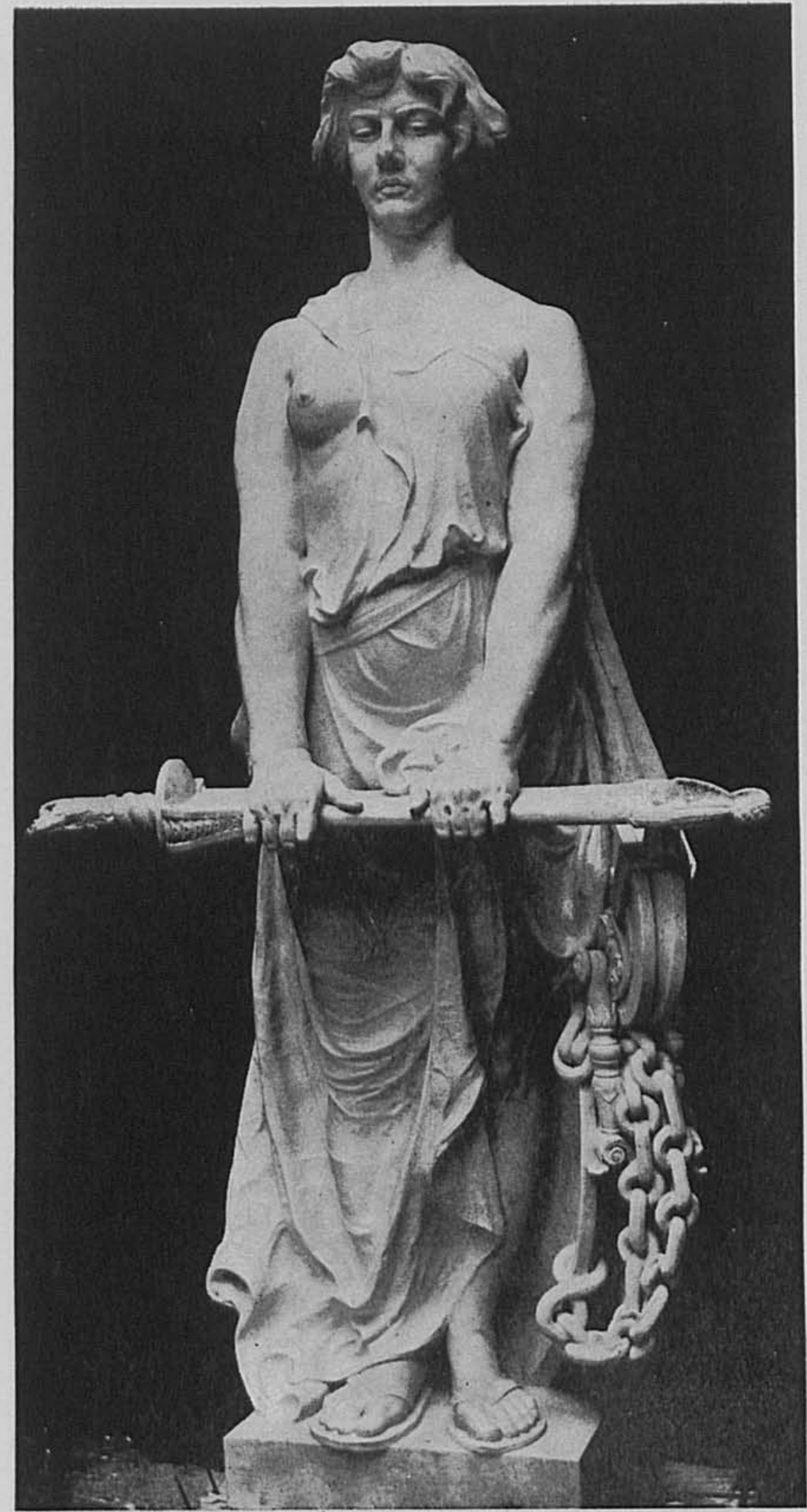

12. Enrique Guerra: "La Justicia”. Mármol, 1909. En Jalapa, Veracruz. 


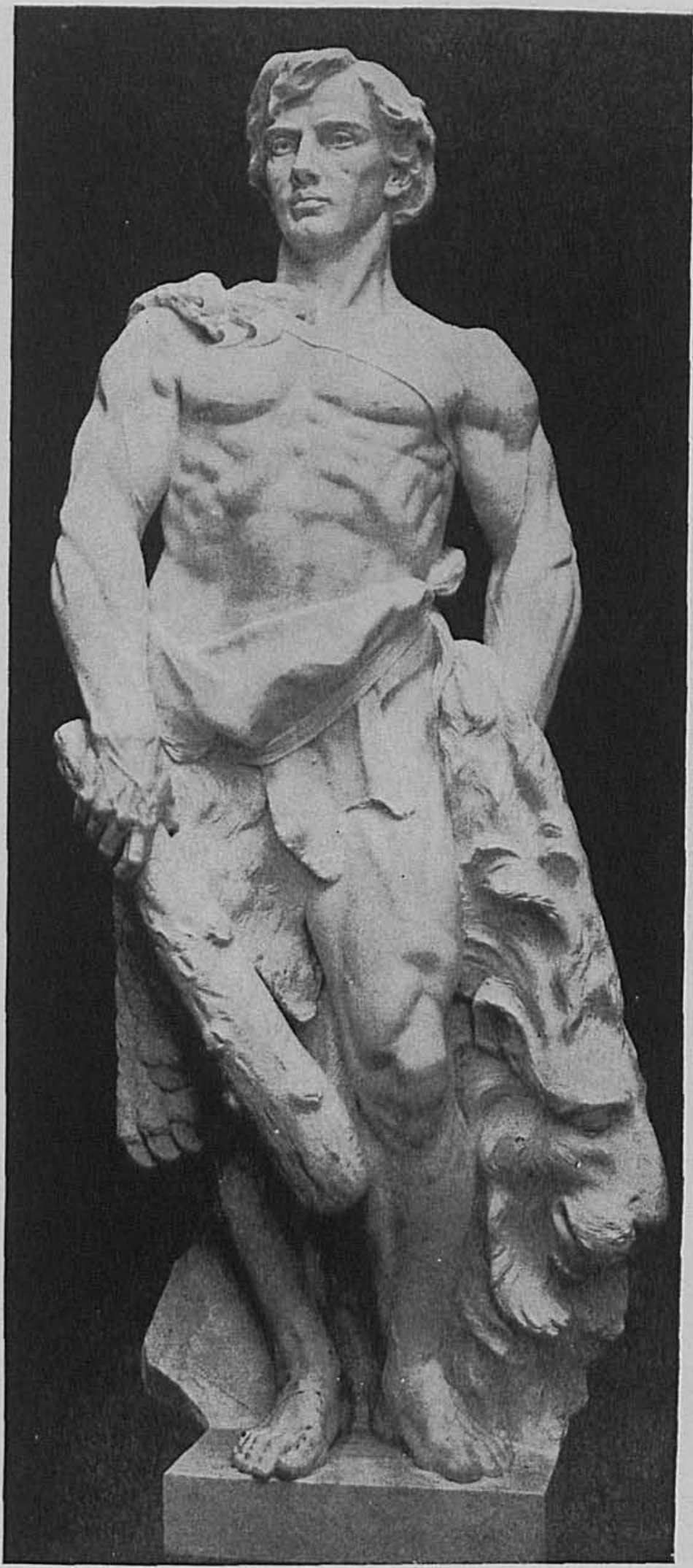

13. Enrique Guerra: "La Fortaleza o la Fuerza". Mármol, 1909. En Jalapa, Veracruz. 


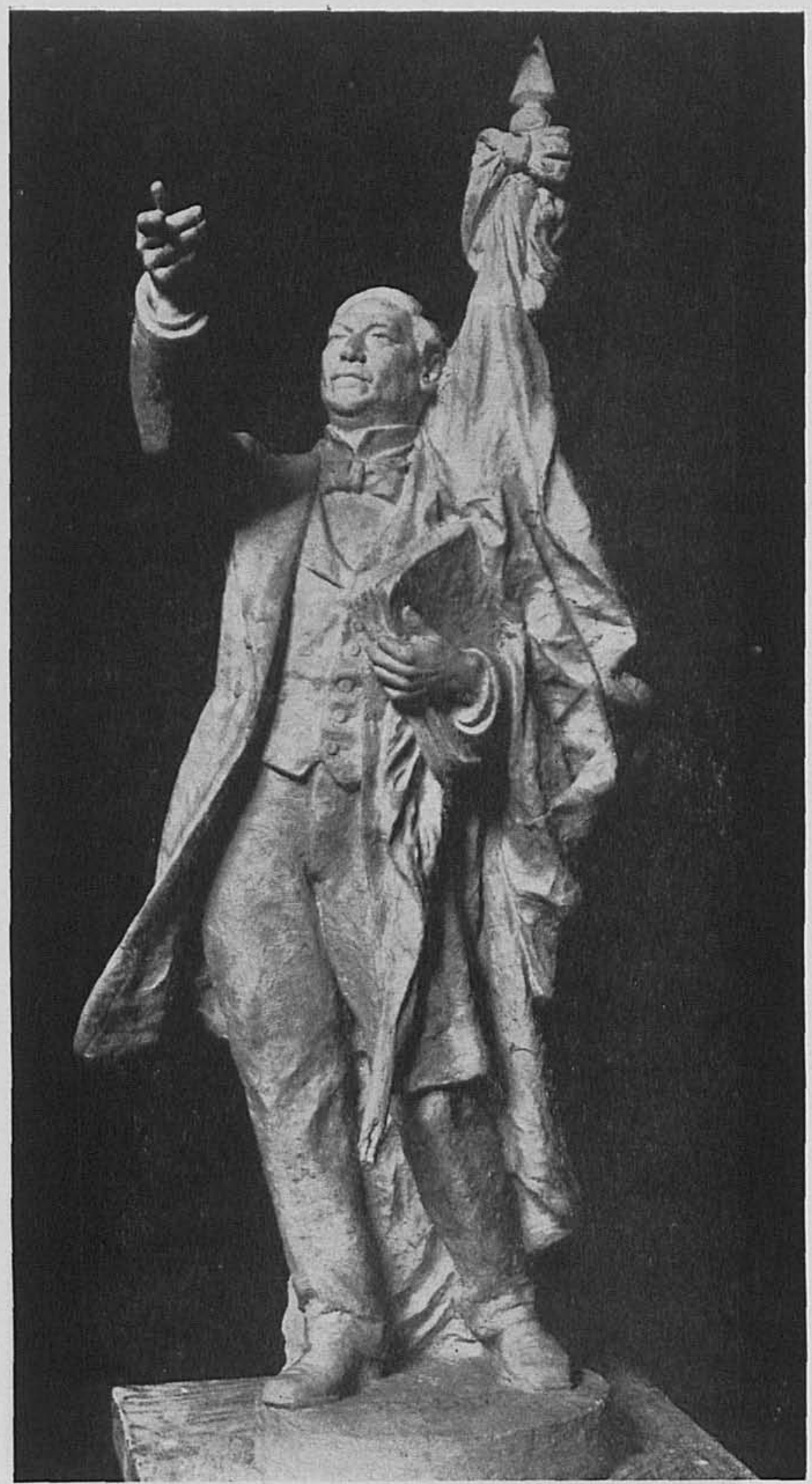

14. Enrique Guerra: original en yeso de la estatua de Benito Juárez. México, 1910. 
DOI: http://dx.doi.org/10.22201/iie.18703062e.1965.34.809

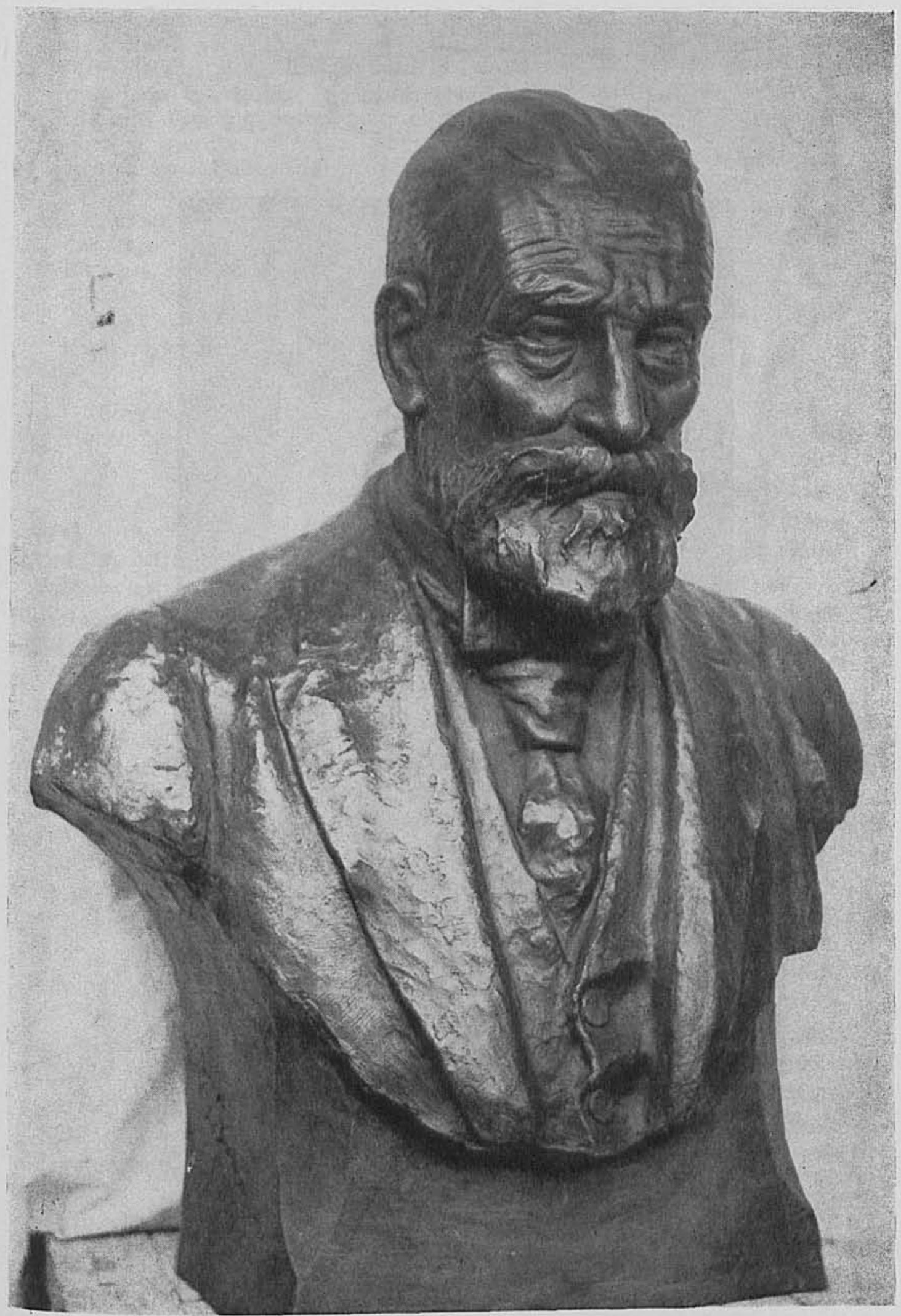

15. Enrique Guerra: "Don Silvestre Moreno Cora". México. 1928. En Orizaba. Veracruz. 
DOI: http://dx.doi.org/10.22201/iie.18703062e.1965.34.809

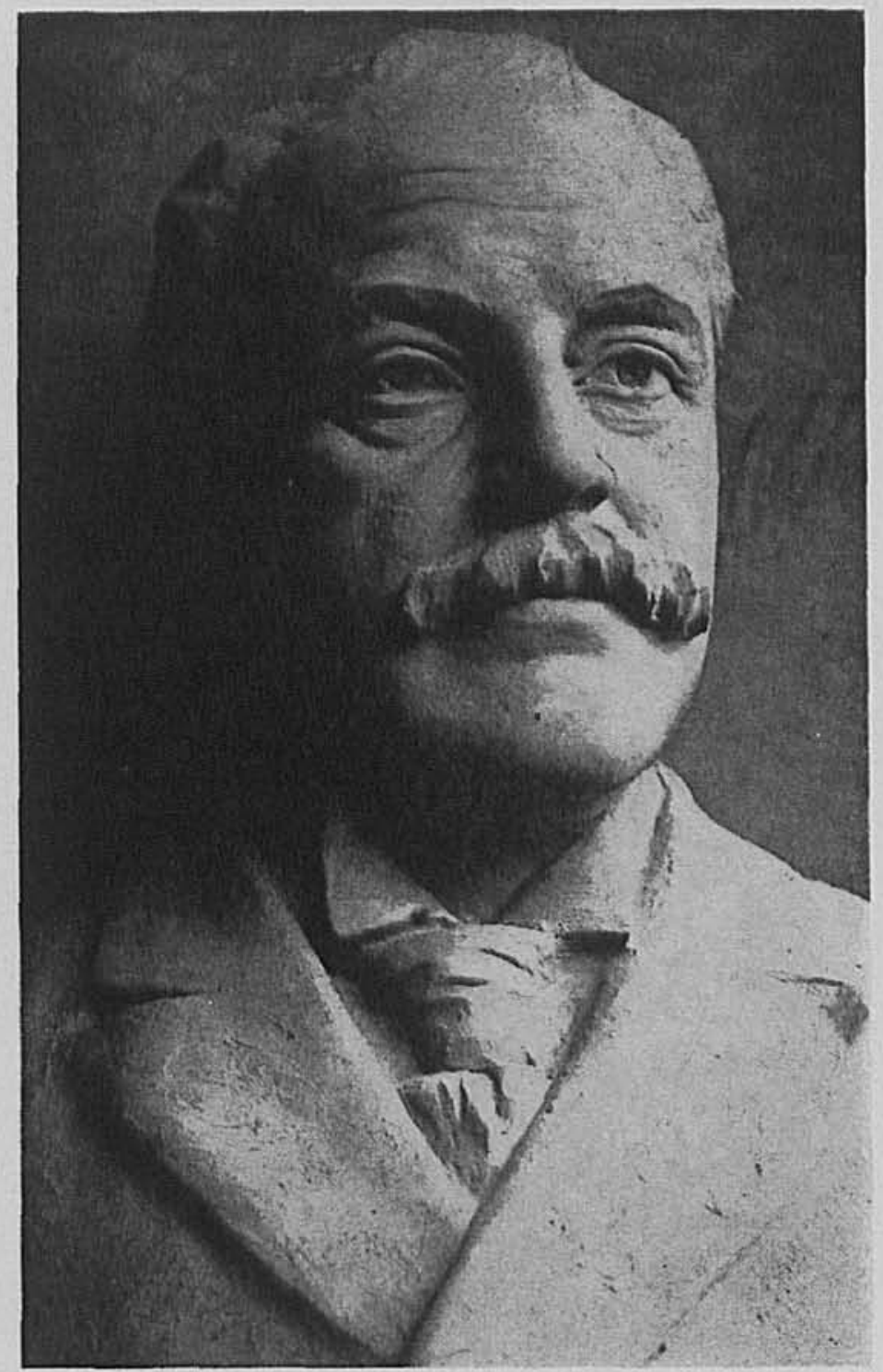

16. Enrique Guerra: "Don Rafael Delgado". Yeso, México, 1911. 
1: : $6^{a}$ Siendo necesario tanto por los escasos elementos que hay en el país para este género de obras como por el corto plazo de que se ! dispone que la talla en mármol de toda o de la mayor parte de la obra se ejecute en Italia, no podrán ser inspeccionadas por el $\mathrm{Sr}$. Arq ${ }^{\circ}$ Mariscal autor del proyecto del edificio y por el Sr. Ing Garcia Cubas Inspector nombrado por la Secretaría, sino los trabajos llevados a cabo en México; los que se efectúen en Italia tendrán que quedar bajo la vigilancia de la persona que designe la Secretaria de Relaciones. El transporte de la obra concluida desde el sitio en que se ejecute hasta el edificio será por cuenta de la propia Secretaría.

8. El plazo es improrrogable salvo el caso de fuerza mayor debidamente comprobada.

[Firman:] José Algara.-Enrique Guerra.-Vo Bo Nicolás Mariscal.Conforme Antonio García Cubas". 7

Causa extrañeza esa estipulación de tan difícil, costosa y arriesgada operación, como èra la de enviar a Italia unos yesos enormes (2.70 metros de altura) y luego traer de allá las voluminosas y pesadísimas translaciones en mármol; la explicación la da en partes el contrato: sin duda pareció más difícil importar los enormes bloques en bruto y ya dice que aquí no había artesanos, es decir, tallistas competentes, por otra parte es evidente la imposibilidad de que Enrique Guerra, él solo, labrara las cinco esculturas en año y medio, menos los varios meses que tardaria el mármol en llegar. Pero lo más extraño es esto: la primera cláusula del contrato dice, claramente, que Guerra se compromete a "labrar en mármol los modelos... habiendo desarrollado previamente al tamaño de ejecución dichos modelos"; corrigiendo la defectuosa redacción citada, creo que debe entenderse que el escultor se obligaba a hacer los modelos, sin duda en yeso (como los hizo) y, como la cláusula $6^{\text {a }}$ establece que se labrarán en Italia, era de suponer que Guerra iría a tallarlos alli, ayudado de tallistas que aquí no había. Eso habría sido lógico y adecuado; pero lo ocurrido fue que Guerra se quedó en México y fue a Italia el señor Bertucci y Luigi y el pasar los yesos àl mármol se hizo en Carrara, en el taller de Alessandro Lucchetti, como consta en varios documentos que conserva el archivo de nuestra Secretaría de Relaciones Exteriores. ¿A qué se debió tan extraña solución? ¿Por qué no fue Guerra con sus obras? Ninguno de los documentos que he tenido a la vista aclara ese punto, aunque muchos hay que

7 Expediente 1/121.31/1, legajo 1, del Archivo General de la Secretaria de Relaciones Exteriores. 
se refieren al envio de los modelos, a su llegada, a la talla en mármol y a la remisión y recibo aquí de las estatuas definitivas.

Uno de los documentos más explícitos es un informe del Cónsul General de México en Génova (oficio No 142, del 4 de mayo de 1909). a la Secretaría de Relaciones Exteriores, en el que transcribe integra una carta que el señor Bertucci Luigi dirigió al Cónsul desde Carrara, la cual dice:

Hago notar a usted, por medio de la presente, que sali de México en Enero de 1909 con el encargo de venir a Carrara para vigilar todo lo necesario para la regular y pronta ejecución de las cuatro estatuas y del águila de mármol que deberán adornar el palacio de Justicia [sic] del Gobierno mexicano... Llegado a Carrara en Febrero del corriente año, me di prisa en procurar el envío de los grandes modelos de yeso... Hecha la provisión de los mármoles de una calidad superior, y siempre bajo mi vigilancia y la elección de artesanos capaces y expertos, desde hace algunos días los trabajos proceden con gran celeridad y precisión... [Enseguida solicita la influencia del Cónsul para conseguir una prórroga de un mes al plazo fijado] para asegurar mayormente la ejecución perfecta y artística de las estatuas, pues sé lo mucho que se preocupa el artista por obtener una fiel interpretación de sus propios modelos. La semana pasada hemos tenido en el taller del Sr. Lucchetti la visita del Director y [del] Secretario de la Academia Real de Bellas Artes de Carrara, llegados expresamente para ver y examinar los modelos y los mármoles de lás citadas estatuas ... 8

En resumen: celebrado el contrato en noviembre de 1907, el escultor Enrique Guerra se puso a trabajar, en el curso de 1908 modeló las obras, los grandes yesos fueron empacados (uno de ellos llegó roto a Italia, pero fue inmediatamente restaurado), en los primeros meses de 1909 estaban ya en Carrara y durante ese año se procedió a transladarlos al mármol; en 1910 fueron enviadas a México diez grandes cajas: cinco con los modelos en yeso y otras tantas con los ejemplares en mármol. Muy probablemente -más bien, seguramente-Guerra les dio aquí los toques finales y fechó y firmó los mármoles, como se puede ver en la base de "Templanza", que hoy está en el Bosque de Chapultepec. A mediados de 1910 quedaron colocadas en el sitio que les estaba destinado, en un cuerpo de remate de la fachada de Relaciones Exteriores, en la avenida Juárez, las cuatro grandes estatuas que simbolizan las cuatro virtudes: "Fuerza", "Justicia", "Prudencia" y "Templanza", y en

8 Expediente II/123.21 "08"/2, legajo 42-22-30 del Archivo General de la Secretaria de Relaciones Exteriones. 
medio, en el eje central de la fachada, el águila a que se refieren los documentos anteriores que, desde luego, no era solamente esa ave sino todo el emblema o escudo de armas de la República Mexicana.

En su sitio estuvieron esas esculturas algo más de dos décadas. En 1923, al hacer grandes reformas al edificio de Relaciones Exteriores se cambió totalmente su fachada sur, o sea la de la avenida Juárez. En esa fecha las esculturas de Guerra fueron quitadas de su lugar, y "arrinconadas" y de hecho olvidadas, en el inconcluso Palacio Legislativo. Para el lector que no lo recuerde o no lo haya conocido valga esta aclaración, que es una línea de la historia de esta ciudad: el "Palacio Legislativo", como lo llamábamos todos, aunque nunca llegó a serlo, proyectado por el arquitecto francés Emile Bénard, quedó inconcluso al estallar la revolución y nunca fue terminado; su enorme estructura de hierro, rodeado por una barda de láminas de zinc, cubría el área que hoy ocupa el monumento a la Revolución (que debió ser el centro y la cúpula del Palacio), con las rampas y jardincillos que lo rodean, y de 1911 a 1932, aproximadamente, estuvieron alli trozos de mármol, materiales de construcción, esculturas que debían ornar el edificio y otras que por alguna razón, y muchas veces por alguna sinrazón habian sido quitadas de sus sitios originales; en fin, durante veinte años o poco más, aquello fue algo así como un vasto "cuarto de triques" de la ciudad de México.

Alli permanecieron, durante ocho años, las monumentales estatuas de las cuatro virtudes, de Enrique Guerra, hasta que en 1931, ignoro por qué circunstancias, el Presidente Ortiz Rubio ordenó que fueran colocadas en el Bosque de Chapultepec, pero entonces el coronel Adalberto Tejeda, gobernador del Estado de Veracruz, reclamó para su capital, Jalapa, algunas de esas obras, seguramente porque Guerra habla nacido allá. El resultado fue que la estatua de la "Templanza" fue llevada y hoy está presidiendo la fuente del lado sur del Bosque de Chapultepec; ${ }^{\circ}$ las otras tres están colocadas en este orden: "Prudencia", "Fuerza" y "Justicia", en la glorieta del Paseo del Ayuntamiento, en Jalapa, Veracruz. En cuanto a las figuras del escudo nacional, me ha sido imposible saber su actual paradero (Figs. 10 a 13).

9 Al pie de la estatua, en el mismo mármol de ella, tiene esculpido: E. GUERRA. MEX. 1910. Actualmente la figura está sobre una base y con un respaldo de piedra, y en la parte posterior de este último se lee la siguiente inscripción: "La Templanza" / fue esculpida en / 1910 por Enrique / Guerra de Jala / pa Ver, a ini / ciativa del C. / Presidente de / la República Ingo / Pascual Ortiz Ru- / bio se colocó en / este sitio / Noviembre 1931. 
En esos primeros años de su retorno fue Enrique Guerra un escultor ampliamente conocido y bastante solicitado, ambos calificativos en proporción con el medio, siempre estrecho, en que ha vivido ese arte; asi lo demuestran las obras que hizo ya por encargos oficiales ya para clientes particulares: estatua en bronce de Benito Juárez, en 1910 (Fig. 14), para el monumento en la ciudad fronteriza que lleva el nombre de ese Presidente: al siguiente año la estatua sedente, también en bronce, del pedagogo Enrique Rébsamen, que está en el patio de la Escuela Nacional de Jalapa; cinco retratos, en busto: de Teodoro A. Dehesa, de Joaquín Pimentel, de la actriz Virginia Fábregas, del novelista veracruzano Rafael Delgado (Fig. 16) y, en 1912, el del Presidente Francisco I. Madero.

González Peña, en el cariñoso artículo necrológico que publicó al mes de la muerte de su amigo, luego de mencionar los encargos de las estatuas para la Secretaría de Relaciones Exteriores y de la de Juarez dice, refiriéndose al período que siguió: "Entretanto... ocurría con Enrique Guerra lo que con tantos escultores mexicanos. En la plenitud de su esplendor artístico, consciente de su arte y de su fuerza, capaz y voluntarioso de hacer, de realizar, de acumular una obra personal y magnifica, se vio constreñido - una vez que hubo de transcurrir breve lapso- a la inactividad." Y más adelante continúa: "Sentía, sabia que podía afrontar mucho; bullían en su mente espléndidas ideas creadoras. Pero al escultor no le basta equerer y asaber para hacer... [en contraste con el poeta, el músico, el pintor, cuyos materiales para su medio de expresión son más fácilmente asequibles]. El escultor no, como no se conforme con la vida fugaz del barro. Los mármoles y el bronce no están a su alcance; ha menester el escultor que un rico o el Estado soliciten y aporten, para que él cumpla su misión de arte. Y aquí en México, sobre que los ricos sólo gustan de la emuñequería funeraria, el Estado se preocupa muy poco de la escultura'. ${ }^{10}$

Son muy explicables esos reproches amargos, pero son justos sólo en parte. González Peña olvidaba, cuando escribfa eso en 1943, que Ias circunstancias sociales de México, en la década que siguió a 1912 , fueron tales que, naturalmente, cuando la existencia de los gobiernos y los intereses y las vidas de los individuos estaban en peligro grave y cotidiano, la protección y el impulso al arte necesariamente habían de quedar postergados.

Pasada la tormenta -como justamente la llamó Vasconcelos en su libro que a tal época se refiere- el Estado volviớ a estar en posibilir

10 González Peña, Op. cit. 
dad de cumplir sus funciones en el campo de las construcciones officiales, el culto cívico, el ornato de las ciudades; etc., que requieren la obra escultórica. Entonces Enrique Guerra volvió a recibir algunos encargos oficiales aunque, es verdad, no en la proporción en que: los tuvo en su juventud, cuando su feliz regrèso de Europa. En 1924 hizo la estatua sedente y los relieves en bronce, para el monumento al doctor Eduardo Liceaga que se levanta en una pequeña plazoleta, en la confluencia de las calles que hoy llevan los nombres de avenida Chapultepec, doctor Río de la Loza y avenida Cuauhtémoc. En $1928 \mathrm{cl}$ busto, en bronce, del licenciado Silvestre Moreno Cora, para Ia Escuela Normal de Orizaba, Veracruz. Hacia ese mismo tiempo otra estatua de Rébsiamen, muy diferente de la de 1911, pues esta segunda represénta al maestro de pie, labrada en piedra chiluca, acupa uno de los ángulos del primer patio de la Secretaría de Educación Pública. En 1929 hizo el monumento funerario para la tumba de su amigo, el ilustre músico Cärlos J. Meneses, en el Panteón Francés de La Piedad. 11

Además de su labor creadora, como escultor, Guerra ejerciỏ largamente la enseñanza. Recién llegado de regreso al país fue nombrado Profesor de Dibujo y de Modelado en la Escuela de Bellas Artes, es decir, en la propia escuela en que él estudió años antes, puesto que ocupó de 1907 a 1915. Después fue transladado a la Escuela Nacional Preparatoria, para las mismas clases, desde 1916 hasta 1926. El año de. 1922 fue profesor en la Escuela de Maestros Constructores. Desde 1927 a 1940 enseñó modelado en diversas escuelas secundarias oficiales y en colegios particulares.

A esa actividad docente se refiere González Peña, en un tono despectivo que no me parece del todo justificado; dice: "A falta de monumentos que no se proyectan y levantan, no obstante que por proyectar y levantar hay tantos; a falta de mármoles y bronces que hermosearian y dignificarian tantos lugares públicos, dando de paso aliento y pujanza a un arte de vigoroso sello mexicano, el Estado no tiene otra cosa que ofrecer a nuestros escultores -incluso a los grandes- que modestas,

11 El maestro Meneses y el escultor Enrique Guerra, además de la estrecha ainistad personal y de sus respectivas familias, que los ligó, fueron por muchos años vecinos de la misma calle, entonces llamada de Magnolia, en la colonia Gucrero (la familia Mencses en el No 206 y la familia Guerra en el No 224); calle que hoy lleva el nombre de Carlos $f$. Meneses.

12 González Рейa, Op. cit. 
clasecillas de modelado en las escuelas; o la cátedra en Bellas Artes, para acrecer el número de los desengañados." 12

Precisamente en una de esas "clasecillas de modelado" fui yo alumno del maestro Enrique Guerra, en el Colegio Francés, el año de 1927. Lo recuerdo muy bien: grueso, de mediana estatura, el pelo ensortijado y entrecano; nos impartía sus enseñanzas con amabilidad pero con visible poco interés: él más que nadie se daba cuenta de la inutilidad de esas clases a las que sus alumnos asistían sólo por exigencias del plan de estudios. Para nosotros, la clase de modelado era una diversión más que un esfuerzo; yo no sé de ninguno de mis compañeros que haya hecho después el más pequeño intento como escultor. Dos horas cada quince días estábamos una treintena de muchachos, entre los catorce y los diez y seis años de edad, de pie junto a unas largas y estrechas mesas; frente a cada uno había una tablita sobre la mesa y un montón de magnífico barro. Se suponía que a lo largo del curso deberíamos hacer primero relieves sencillos y luego modelados en bulto redondo. Los modelos eran hojas, flores (los imprescindibles alcatraces), o pies, manos y cabezas de yeso. Algunos compañeros demostraban cierta destreza y alguna aplicación, a ellos el maestro Guerra los atendía con sus indicaciones y consejos más frecuentemente que a los demás. Yo era muy torpe para modelar el barro con los dedos y para manejar los estiques, peor; nunca pude hacer nada que fuera ni medianamente aceptable. Pero recuerdo lo divertido que fue cuando debimos modelar un caracol. A cada alumno se nos proporcionó un caracol vivo; cuando llegamos a clase los animalitos estaban quietos y metidos en su concha, pero un rato después empezaron los problemas. Era obligatorio, antes de modelar la forma requerida, hacer de barro la base que la sustentaría; el procedimiento era hacer unos rollitos o barras cilíndricas, como de dos centímetros de diámetro y tan largas como el ancho de la tabla que hacia de banco de modelar, debian ponerse los rollitos uno junto a otro hasta cubrir la tabla $y$ luego aplastarlos y alisar la superficie con el estique para lograr una capa de barro uniforme, sólida y plana. Yo ni eso pude nunca hacer correctamente. Pero el día de los caracoles, mientras preparábamos los rollitos y demás, los bichejos empezaron a moverse y sucedia que, como eramos tan torpes, mientras con dificultad empezábamos a dar forma a la bola de barro, ya el "modelo" lenta y parsimoniosamente habla caminado y estaba junto al "modelo" vecino o subiéndose al barro o bajándose de la mesa; entonces cogfamos el caracol y lo poniámos donde debia estar pero el animal, al sentirse tocado, se escondía en su 
concha y nosotros nos desesperábamos porque, naturalmente, no queríamos copiar sólo la concha sino todo el molusco, lo más completo y espectacular posible. Todo eso daba Iugar a que trajéramos los animalitos de un lado a otro y nadie hacía nada a derechas. Finalmente, cada quien modeló lo que pudo y quiso, el maestro Guerra revisó los esperpentos que hicimos y anotó en su libreta lo que juzgó conveniente $y$, en cuanto dio por terminada la clase, sucedió lo peor: todos, con maldad infantil, sepultamos a los caracoles en el barro y abandonamos el salón. Cuando, a pocos días, debió darse la clase a otro grupo, encontraron los caracoles muertos y el barro echado a perder y hubo que tirarlo y comprar más, por lo que los Hermanos Maristas que dirigíán el Colegio se pusieron furiosos, tanto más que no pudieron castigar a ninguno, porque aquello fue la Fuenteovejuna de los caracoles, en que toda la clase era igualmente culpable.

Quede aquí ese paréntesis de recuerdos personales, con mi voto de gratitud para el maestro, que siendo escultor experto, de vocación y fama, tuvo paciencia y amabilidad para el joven alumno torpe y desaplicado.

Las últimas obras de Guerra fueron: un retrato, en yeso, de Luis G. Urbina, sin duda basado en fotografías, pues lo hizo én 1938, cuatro años después de muerto el poeta; los relieves y decoraciones escultóricas para el monumento a Bolívar en la fuente del jardín de la colonia Chapultepec-Polanco; "Luz y sombra", yeso, de 1942 y "La Sedienta", en mármol, propiedad del doctor Enrique Bullman.

El escultor Enrique Guerra murió el día 3 de febrero de 1943, rodeado de su esposa y sus tres hijos, en su casa, el No 224 de la calle Carlos J. Meneses. Fue sepultado al día siguiente, por la tarde, en el Panteón Moderno.

No toda la obra de Guerra es ahora fácilmente accesible para su conocimiento y estudio. Desde luego, parte de ella, sobre todo la realizada en París, nos es casi desconocida, o bien sólo podemos apreciarla parcialmente porque en algunos casos, por ejemplo "Voluptuosidad", el autor trajo consigo el modelo en yeso, pero la versión definitiva en mármol quedó en el extranjero. Los retratos que sabemos modeló, tal vez se conserven, pero debo confesar que los desconozco. Finalmente, sólo he podido mirar algunas de las estatuas que hizo para monumentos públicos, de varias de ellas no es fácil obtener buenas fotografías y están dispersas en sitios muy distantes: Jalapa, Orizaba, México, Ciudad Juárez. 
Con las limitaciones mencionadas, del examen de la obra de Guerra se pueden derivar algunas conclusiones, acaso no definitivas, pero que corresponden a la finalidad de estas páginas, estudio inicial que sólo pretende aportar algunos datos $y$, sobre todo, incitar al posterior $y$ más completo examen de la escultura mexicana del siglo xix.

En la obra de Enrique Guerra es claramente perceptible su trayectoria artística.

Del academismo inicial de su época estudiantil son magnífica muestra los dos yesos de 1899 (Figs. I y 2). Los temas de uno y otro son anécdotas de la historia de Roma: La composición es simple en el "Coriolano" y un poco menos en el "Asesinato de César", pero en ambas hay defectos: en aquél, las figuras plorantes de la izquierda y el impertinente detalle del espia, a la derecha, atraen más la atención que la figura del centro, en el mismo primer plano, que es el personaje principal. En el segundo relieve, defecto es que la estatua de Pompeyo, que debe ser parte muy secundaria, recibe gran énfasis $y$ : casi nulifica al cuerpo caído a sus pies, que es el asunto mismo y causa de la acción y sentimientos de toda la obra: fuga y terror que expresan los demás personajes. Se dirá que una crítica así es, también, academista, lo que es verdad, pero yo creo que la crítica, es decir, la vat loración de todo arte, debe hacerse desde un doble : punto de vista (cuando ello es posible, que no siempre lo es): el nuestro actual y el que corresponde al propósito del autor, pues me parece del todo injusto $e$ inadecuado juzgar a un artista exigiéndole motivaciones, intenciones y finalidades que no quiso ni pudo tener. En las composiciones referidas los ejes son rígidos, lo que produce estatismo y frialdad; pero es bueno el tratamiento de los planos y hay gran cuidado en el modelado, sobre todo en el tratamiento clasicista de los paños.: En conjunto, esos relieves son muy estimables y dignos de los elogios que en su día recibieron y más aún habida cuenta de que los modeló un alumno que todavía seis o siete años antes estaba obligado a alternar, sus estudios preparatorios con su trabajo de talabartero.

Las obras de la segunda etapa, la de París, son totalmente diferentes, y no digo contrarias porque mantienen en común con las anteriores la buena calidad del "métier" o técnica del escultor. En su obra parisiense, que se prolonga hasta los dos primeros años de su regreșa a la patria, los temas son muy diversos: desde los clásicos ("Prometeo": "Amor y Psiquis"), los anecdóticos realistas ("La caza del oso"), pero se nota proclividad a lo alegórico y simbólico ("El sueño de Sulamita". "Voluptuosidad", "Épave") de un modo que es frecuente en el final 
del siglo, aunque sus raices están muy atrás, en Delacroix y Puvis de Chavannes por ejemplo. Es claro que me refiero al género, no a que esos grandes pintores sean antecedente directo de las esculturas de Guerra. En estas últimas, todo lo que en su primera época era rigidez y frialdad, en su etapa de París se vuelve movimiento, suavidad y voluptuosidad; los ejes de composición ya no son rectos sino leves curvas, el arabesco se enriquece, las anatomias suelen disolverse en penumbras, de olas en "Épave" (Fig. 7) de ropas en "Crisálida" (Fig. 5), o se repliegan en sí mismas, como en "Thais" (Fig. 6), dando así un toque de indefinición y de misterio, que es una de las tendencias románticas que heredó el simbolismo. El tratamiento formal procede de dos fuentes: reminiscencias del gusto por la morbidez y cierto aire decadente de los continuadores de Carpeaux y también la gran influencia de Rodin. Atrevida parecería esta última afirmación, pero no lo es sino para quienes Rodin es solamente el autor del "Pensador" y del "Balzac", pero Rodin fue, en realidad, un creador multiforme y contrastado, no es el caso analizarlo aquí, pero basta una ojeada a la "Crisálida" de Guerra (Fig. 5) y al busto de Madame Vicunha, de Rodin, para entender lo que contiene la aserción arriba asentada.

Una tercera etapa en la obra de Guerra son sus grandes estatuas: los mármoles para la Secretaría de Relaciones Exteriores, los bronces de Juárez, de Liceaga, etcétera. En todas esas obras, muy acertadamente (dadas sus dimensiones y la distancia a que deberían de ser miradas) la composición es sencilla pero nunca rígida y el tratamiento de los planos que dan los volúmenes es acusado, enérgico, mostrando un consciente y loable deseo de seguir al Rodin de las esculturas monumentales.

En conclusión, Enrique Guerra es artísticamente un escultor del final del siglo xIx; en esa época se formó, en esa época produjo gran parte de su obra y dentro de sus directrices estéticas supo expresarse con gran dignidad y con un ejemplar oficio. 